\title{
Notes Toward Fresh Ideology
}

\author{
Richard M. Morse
}

\section{Evanescent Paradigms}

For a Latin Americanist who is getting on in years the shifts of paradigm by which we construe our region of interest have accelerated to a breathless pace. Yet academic solemnity is such that mounting chaos is presented as linear advance toward more perfect knowledge. It is as though university departments, guilty of drunken driving, were

administering their own sobriety tests.

Think of what we've been through. In the 1940s and into the 1950s there was agreement in all the Americas, except in cranky socialist or fascist corners, on some brand of liberal evolutionism. It rested on sanguine assumptions about the generative forces of industrialization and the stabilizing influence of a literate middle class having a stake in a modern economic order. By the mid-50s it appeared that international capitalism was not wholly beneficent. One began to hear that it had sinister, imperialist features and that to countervail them the client countries required centralized planning and "structural" change to correct for cultural differences and a built-in economic handicap. As the plot thickened, the horizons of the early $60 \mathrm{~s}$ clouded over. Secular determinisms came to the fore: entrenched elites who were cooptative rather than self-renewing or circulatory; permanent disadvantage in world markets; an international system that was predatory as well as asymmetrical; internal colonialism that had persisted since the sixteenth century or perhaps, in Mexico and Peru, the fourteenth. At this point the Cuban Revolution became a fascinating example of (however one interprets it) charismatic extrication or heterodoxy by external subsidy.
In the late 60 s and early 70 s the worst fears were realized. Revolutionary impulses were stubbed out. The military shed their disguise as modernizing technocrats and intervened to erect a state apparatus that was, in the socialscience euphemism, frankly "exclusionary" with respect to popular strata. When the clips were down the generals were not umpires but vampires. Because this calamity affected countries with prestigious academic cadres, their "bureaucratic-authoritarian" model, improvised overnight, became doctrine for the whole region save for the shopworn but still bothersome case of Cuba, now left to specialized Cubanologists. By the mid-70s it appeared that the soldiers had bitten off more than they could chew, that popular suffering and indignation demanded redress, and that elites were not sufficiently monolithic and deferential to pledge eternal allegiance to regimes whose competence did not extend to economics. By now, what's more, popular uprisings in small Caribbean nations were stealing the spotlight, laying under question the diagnoses from privileged academic vantage points. Blue-ribbon analysts promptly supplied fresh models for redemocratization in conference papers, sometimes at the very moment when their bureaucratic-authoritarian treatises were monumentalized as books.

Paradigm shifts have clearly accelerated beyond the safety margin. For if the replacement frequency has shrunk to quinquennial intervals, how can paradigms ever be substantiated? Bear in mind that graduate students are the principal source of data for validating theoretical flights of senior professors. But if dissertations take eight years from conception to divulgation, they
My middle ground has Latin America for its arena. Here the level of "policy" concern presents dramatic contrasts among Brazil, Cuba, and Chile while the level of Nietzschean "spiritual" concern tranquilly assimilates all of Latin America to the Rest of the West. For the present argument we simply assume Latin America to be a civilization unto itself with its own political culture. 
will forever be documenting threadbare propositions. The planned obsolescence of capitalism triumphs in the academic marketplace, and scholarship pours into a perpetual black hole.

\section{Latin America as a Civilization}

Now it may be that experience outruns our capacity to interpret it. But much depends on what we mean by experience. If we mean the familiar dilemmas posed by sudden deficits or military confrontations, then "policy"is ipso facto reactive and improvised. Outcomes depend on the skill, and above all wisdom of those who devise it. If we mean a large sea change in our spiritual condition, there may be the occasional Kierkegaard or Nietzsche who will detect it, but we common mortals must live out the experience before we can, generations later, make out their Delphic meanings. My concern here lies between these extremes. I look for understandings that can set manageable context for quotidian events without invoking spiritual absolutes.

My middle ground has Latin America for its arena. Here the level of "policy" concern presents dramatic contrasts among Brazil, Cuba, and Chile while the level of Nietzschean "spiritual" concern tranquilly assimilates all of Latin America to the Rest of the West. For the present argument we simply assume Latin America to be a civilization unto itself with its own political culture. To identify this culture would clarify the logics of political action in the region along with many conceptual confusions of the past fifty (or two hundred) years. What's more, if there's a chance that Latin America may soon represent a world and not simply a Third World condition, there is added reason to think toward political discourse of more fixity and universality. We do not seek, that is, to hone local definitions of state, person, and society in Brazil or Mexico. We propose instead that Brazilians and Mexicans drop the prepositional phrase from such terms, as Vitoria and Hobbes did.

This universalist aspiration was dear to Latin American neo-Hegelians and phenomenologists of the 1940 s and early 50s. Leopoldo Zea and his Mexican colleagues sought in Mexican-ness (lo mexicano) a concrete form of $l o$ humano, valid for any person in this situation: "Always concrete awareness of a determined reality. Yesterday awareness of European man, today of the (hemispheric) American, in the future awareness of every man in whatever circumstance or situation." (MIRO QUESADA, 1974, p. 222.) The ecumenical impulse soon collided with functionalist and Marxist orientations in the 1950 s and 60 s, when a new generation of social scientists like Florestan Fernandes believed that "sociologists of underdeveloped and dependent regions should not compete with those from research centers in the central nations. Whe should focus our efforts on systematic empirical research into the fundamental problems of those regions (...); and as for formal or systematic sociology, we should limit ourselves to consuming, wherever and whenever necessary, the results of the work of those centers" (FERNANDES, 1977, p. 195-6).

Zea, at this stage of his career, spoke from a generous, highly eclectic Heglian perspective and Fernandes from a less generous but still eclectic Marxian one. They in effect resurrected a grand confrontation from nineteenth-century Europe. If, however, Latin America is a black sheep within the "Western" family of nations, a dispute cast in such terms illumines only fitfully the implicit themes of its civilization. I suspected something of the sort when, as part of my self education in the 1950s, I speculated that a pre-Enlightenment Ibero-Catholic heritage may broadly condition the Latin American political agenda. The academic establishment consigns this approach, however, to a pigeonhole discreetly labeled "the distinct tradition" (WIARDA, 1982). North American scholars shy away from so-called historico-cultural explanations because they elude empirical demonstration, while Latin Americans, although more hospitable to flights of fancy, understandably chafe under what seems the "dead hand" of an authoritarian and archaic political culture.

The muddle arises because polemics over Latin America's relation to the Modern 
West are resolved by reference to intellectual canons of the Modern West itself, whereas the case requires a global perspective that allows us to see Western "sciences" as culturally embedded. Louis Dumont stretches our grasp when he lumps world civilizations into those of Homo Hierarchicus and Homo Aequalis (DUMONT, 1977 and 1980) ${ }^{1}$. Like most globalizer he makes no reference, so far as I know, to Latin America. I therefore venture to include it in the Hierarchicus category, for it fits Dumont's broadest generalizations about civilizations that failed to share the "revolutions of values" as it accelerated in seventeenth-century Europe. Why the Ibero Atlantic world desisted I try to explain elsewhere. (MORSE, 1988) But we can dispense with historical pedigrees if we are game to accept Latin American civilization tout court.

The impediment to historical reconstruction is that Latin America is not Japan, where a Dore or a Bellah elegantly traces how Shinto, Confucian, and other traditions are woven into patterns favorable to the industrial ethic. The successful outcome legitimates the traditions. To elicit serious discussion of Latin America's neoscholastic legacy is more ticklish. One is politely suspected of clerical or authoritarian sympathies. Perhaps Liberation Theology will liberate academic minds along with disinherited peasants. But meanwhile Leopoldo Zea's old complaint that Latin American ideologists suffer historical myopia still holds.

Non-Western ingredients of the Latin American heritage of course yield supplementary identifications with Dumont's "hierarchical" civilizations. But when these como to the fore as indigenismo and négritude, they are plucked from context and inserted into alien Western categories of etnicity and identity. To trace how the Amerindian and African presence is in fact interwoven with "creole" culture strengthens our argument, as I will later suggest. But for the moment let us dispense with regional history and eat what's on our plate.

\section{The Western Revolution of Values}

Dumont comes to his study of the revolution of values in the Christian Occident from a scholarly career devoted to the caste society of India. He now turns the Indian "mirror" around to look from a fresh angle at the mental furnishings of the West ${ }^{2}$. India he recognizes to be an extreme case and wholly different from China or ancient Greece. He also acknowledges Western variations between, say, France and Germany with respect to nationalism and individualism. His trick is to define the Western "revolution" so as to yield a principle of discrimination for the West and the Rest.

The two antitheses that support

Dumont's taxonomy are

hierarchy egalitarianism and holism-individualism. Hierarchy and holism characterize most of the societies the world has known. The modern West is an aberrant case. Dumont freely admits that his constructs fall in the shadow of Maine and Tonnies. His reinterpretation, however, differs in key respects. First, he pluralizes both poles of the dichotomy. Second, he implies no developmental sequence; the "modern" pole is a civilizational option, not an evolutionary outcome. Third, he uses mirrors to interpret the "modern" pole in terms of the "traditional" rather than vice versa, and he warmly invites complementary versions of Homo Aequalis from hierarchical cultures other than the South Asian. Finally, the implications he draws from the revolution of values are not at all those of Maine, Tonnies, or even Durkheim; and since implications concern us, we may borrow taxonomy as merely heuristic.

Briefly, Dumont contrasts society seen as a whole (universitas) with society seen as an association (societas). In one case the norm is "order, tradition, orientation of

1 The "aequalis" studies are an ongoing series, some now available as articles.

2 Before reading Dumont's "aequalis" studies I had hit upon the same strategy in El espejo de Próspero. 
each particular human being to the ends prescribed for the society". Man here is a social being, deriving his humanity from society as a whole. In the other emphasis falls on "the attributes, claims or welfare of each individual human being irrespective of his place in society". The "individual" exists by and for himself; society is at best a partnership, at worst a burden or non-human fact (DUMONT, 1971, p. 32). With the ascendancy of individualism the link between immovable wealth and power over men is broken as movable wealth becomes more coveted. "Wealth" attains autonomous status with the momentus consequence that relations between men and things now overshadow those between men and men. This made it logical for the English to abolish slavery in their colonies (long before the Spanish) at the same time that they invited "free" workers to sell their labor, and shorten their lives, in the coal mines.

The transition from holism to individualism is marked in the ideological realm by the factoring out of politics and economics from the complex:

politics-economics-religion-society. "This separation of disciplines tended to hinder the mind from noticing the faulty presuppositions of any particular discipline and to prevent it from adverting to the lack of any coherent intellectual synthesis of the philosophical and theological disciplines. "(MIDGLEY, 1983, p. 26.) Dumont follows this development through five emblematic figures: Quesnay, Locke, Mandeville, Adam Smith, and Marx ${ }^{3}$. Here are some highlights. With Locke individualism, authenticated by property, displaces the hierarchical ideal. Subordination recedes as a social principle in favor of moral obligation. With Mandeville even morals, insofar as they prescribe altruistic action, forfeit their claim on conduct. Because private interests are deemed naturally harmonious, the public good is to be realized through actions not consciously oriented toward it. Private vices may be criminal, to be sure, but this becomes a matter of law, not morality. Mandeville takes us from a post-hierarchical society, wherein persons internalize social order in the form of moral rules, to an economic system wherein each member defines his conduct by self-interest or hedonism, with society serving as a mere

harmonizing mechanism or invisible hand. Kant acknowledges the divorce of norm from fact with his categorical imperative, while Bentham reduces morality to utilitarian calculus. Meanwhile Adam Smith has anointed economics in its acession as queen of the sciences. All this, by the early nineteenth century, leaves the western fringe of Europe and the eastern fringe of North America with a highly eccentric construction of social life.

Marxism is the apparent refutation of this revolution of values. If it failed to catch fire in the Anglo Atlantic world and swept Western Europe in largely revisionist form, it nonetheless became the lodestar of the Russian Revolution, and it continues to bewitch the Third World. But why did Russians need to Russify and orientalize Marxism? (BERDYAEV, 1960, p. 107). And why was Peru's Mariátegui impelled to my thicize the Marxian message, infusing its scientism with the vitalist accents of Sorel and Croce? 4 The answer lies in Dumont's exegesis of Marx's sociological texts that weighs their contradictions against the premises to which he was ineluctably drawn. We cannot reproduce the nuanced argument. To simplify, we summarize three conclusions. First, Marx celebrates the triumph of economism, apotheosizing it from a privileged discipline to a throne from which it cannibalizes sociology, history, and politics. It has passed from the status of humble domestic to that of umbrageous rival to that of abusive mother. Second, Marx ultimately espouses individualism. Revolution is to emancipate man as an abstract, self-sufficient creature. Although the possessive individualism of classical liberals is of course pilloried, in a future society social man will yield to the release of individual interest and

3 The compartmentalization of knowledge in the interest of pedagogical "clarity" some trace to the logician Peter Ramus (1515-72).

4 See Diego Menseguer Illán, José Carlos Mariátegui y su pensamiento revolucionario (1974). 
capacity. Sociology recedes before the primacy that Marx accords to the relation of man and nature over that between man and man. Third, Marx boldly accepted to demythicize the foundations of social life. If his writing drew forensic power from suppressed Promethean and Judeo Christian eschatology, he refused to follow British empiricists in their mythic assumptions about "natural man" and "social contracts"5. He claimed to have erected his argument on scientific bases, to have unmasked social reality, and to have demonstrated that nothing is what it (ideologically) seems. Economic theory is pressed to demonstrate what was hitherto an ethical norm.

This interpretation, emphasizing Marx's economism, individualism, and scientism, gives substance to Foucault's opinion that Ricardo achieved a sharper "epistemic break" than Marx. Marxism, he claims, introduced no real discontinuity at a deep level of knowledge. It fell heir to a hospitable epistemology; it took to nineteenth-century thought like a fish to water. Its conflict with "bourgeois" economics implied not a schismatic recasting of history but mere angry coexistence (SHERIDAN, 1980, p. 70-1). If we accept for the moment that Latin American societies show strong traces of holism, and even if we favor Dumont's judicious argument over Foucault's flamboyant one, we can appreciate why Marxism took so long to strike roots in Latin America, why Mariátegui performed such acrobatics to devise an indigenous Marxism, and why, when neo-Marxisms took the region by storm in the 1960s, the storm was transient even though, like any strong tempest, it changed the mindscape.

What, then, had happened in Western Europe? Economics (as queen) and politics (as hand-maiden) were extracted from the holistic complex leaving religion and society, it appeared, impotent and anecdotal. The pecking order that any community requires was no longer inferred from religion or natural law but furnished by a calculus of naked power. Hierarchy, now unthinkable, fades into bleak, statistically determined social stratification. The new human sciences are ranged on a scale from hard to soft that runs approximately: economics-political science-sociologyanthropology-history-philosophyliterature and the arts. Humanities, or the study of things human, brings up the rear. Geography, perhaps made obsolete by jet travel, instant communication, and martial delivery systems, plays a spectral role. Psychology, depending on its practice, falls anywhere along the scale. If it rips the veil from raw instinct it can dethrone economics, and threatens to do so in both totalitarian and consumerist societies; if it contents itself with the idle play of imagery it lapses back into the humanities. Dumont is worth quoting at length:

\section{"More generally, political theory} stubbornly persists in identifying itself with a theory of power, that is, mistaking a minor problem for the basic one, which lies in the relation between power and values, or ideology. The moment hierarchy is eliminated, subordination has to be explained as the mechanical result of interaction between individuals, and authority degrades itself into power, power into influence, and so on. It is forgotten that this sort of question appears only on a definite ideological basis, namely, individualism: political speculation has enclosed itself unawares within the walls of modern ideology. Yet recent history has afforded us an imposing demonstration of the vacuity of mere power -I mean the vain, if devastating, attempt of the Nazis to base power on itself alone. "(DUMONT, 1977, p. 10.)

If one examines the social-science course offerings, or impositions, of an elite North American university, one quickly spots the bias toward power instead of context, toward what is reductive, instrumental, and systemic instead of nuanced, relational, and culturally responsive. A leading economics department may offer only one one-quarter course on European economic history having the chronological scope to disclose how the discipline itself won primacy in the revolution of

5 Cf. Leonard P. Wessell, Jr., Prometheus Bound, the Mythic Structure of Karl Marx's Scientific Thinking (1984). 
values and how a cost-benefit analysis of the feat might turn out. The bulk of courses assume only benefits as they briskly demonstrate the nuts and bolts of control and management through such topics and techniques as: accounting, econometrics, commodity futures markets, money and banking, financial decisions, science and techonology, development, population in teractions, marketing, linear programming, public finance, fiscal policy, agricultural policy, tax policy, trade policy, human resources, business firms seen as a cooperative "game", economics of medical care, mass media, power and conflict in social systems (treated as game theory), price and allocátion, monetary theory, labor economics, energy modeling, equilibrium analysis, and, to cover all bases, the "economics of uncertainty"

(STANFORD, 1983; p. 339-58).

How would we translate this menu for a Mexican or Brazilian peasant? Clearly the curriculum magnetizes its apprentices toward careers as programmers and manipulators. It crowds out consideration of Lockean "morality", not to mention pre-Lockean holism. Not a single course title includes even the word "democracy".
Much the same can be expected of offerings in political science, with the term "policy" again coming to the fore (Ibid., p. 507-18). Students receive few hints that what are passed off as diagnostic tools are flying buttresses for an ideological cathedral. Mastering the secrets of sheer power presupposes severe contraction of the field of vision and, accordingly, proliferation of more courses. The more that protégés specialize in the arcana of control, the sharper their alienation from the human condition.

The fate of Dickens' perplexed proletarian Stephen Blackpool in Hard Times (1854), for whom economics was "aw a muddle", has gradually become that of society at large:

"Deed we are in a muddle, sir (...). look how we live, an' wheer we live, an' in what numbers, an' by what chances, and wi' what sameness; and look how the mills is awlus agoin', and how they never works us no nigher to onny dis 'ant object - "ceptin awlus Death."

\section{The Question of Ideology}

At this point we grope for clues to the nature of ideology; for if we assume that Lockean or Marxian versions thereof

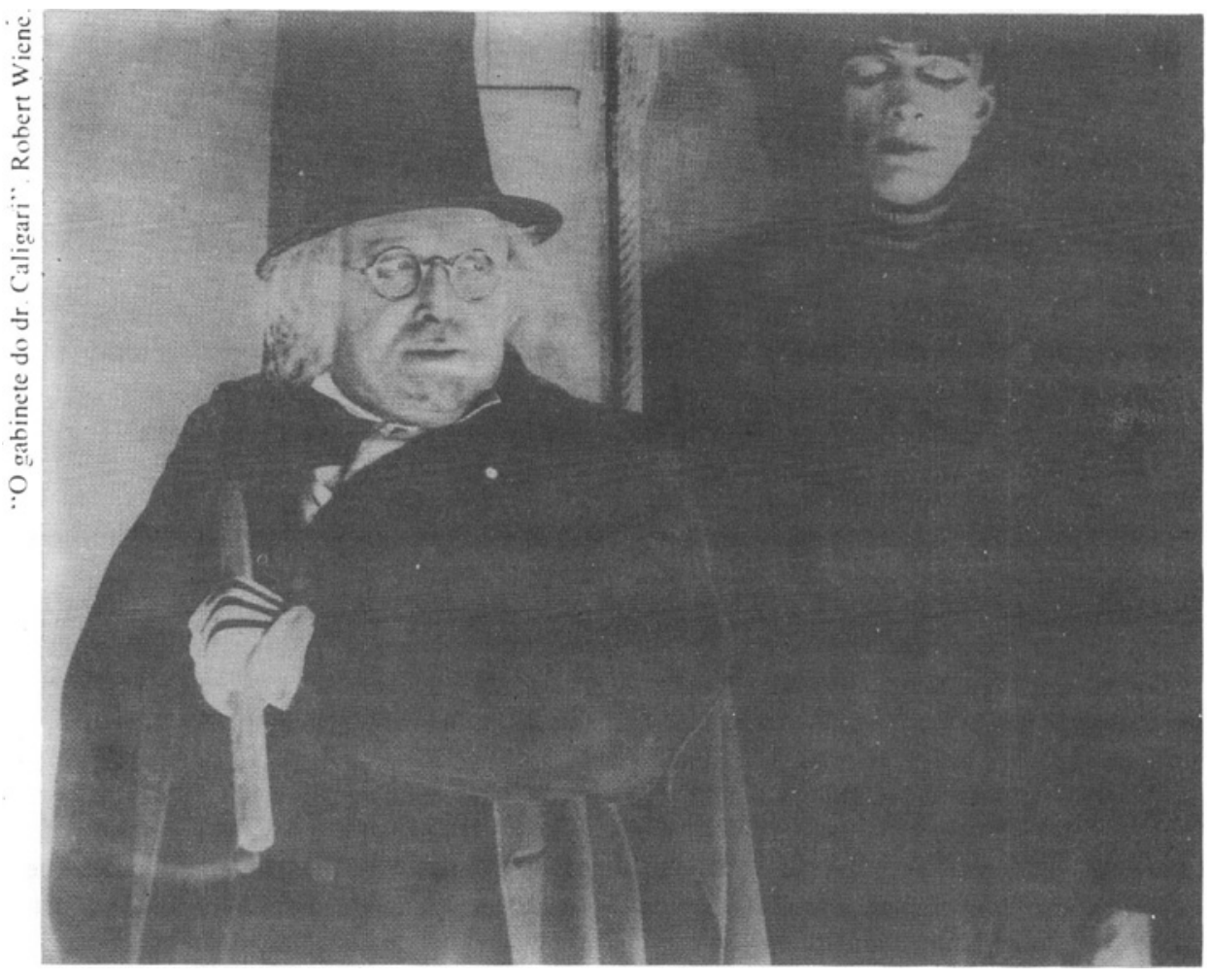


answer the special needs of Homo Aequalis, it stands to reason that the term requires overhaul if it is to mark boundaries for common discourse between the West and the Rest. In the last century ideology was renovated from conflict and compromise between elites and dangerous classes within the bosom of the West. This dialogue echoed throughout the world but could not easily take root, for it made eccentric assumptions about state and society that were coming to be shared by modernizing elites, political economists, and factory hands of the industrializing countries. Elsewhere I address this issue of ideological translatability by analyzing why we associate a "school of economics" with industrial Manchester of the last century and a "school of sociology" with industrial São Paulo of our own (MORSE, 1978, p. 7-34). In the first case, consensual recognition of a national community supported scientific diagnosis and therapy. In the second, the very existence of a national community was questionable; diagnosis would require a sociologically recognizable patient.

In what follows I apply the term ideology to the beliefs and moral sentiments of a community having a shared history and not to an instrumental set of precepts and policy norms that disguise partisan interests. A hegemonic ideology may be said to be the second type successfully masquerading as the first. Those who disparage ideology often do so by pitting. it against philosophy or science. Midgley warns of a gulf between the thinker in search of fundamental truth and the one who chooses or imposes "values" irrespective of their truth or falsity. The inadvertence of ideology to philosophic truth he attributes to the "intellectual amnesia" of the post-Renaissance and Reformation era. Abandonment of the medieval philosophic synthesis in favor of modernist and atheistic presuppositions, he holds, has produced ideological bondage in the moral, intellectual, and spiritual domain from which the only deliverance lies in "rejection of the entire ideological enterprise as such" (MIDGLEY, 1983,p. 159).

For the neo-Marxist committed to science, ideology poses a more complex if less overwhelming challenge. He must acknowledge three versions of ideology: first, a set of beliefs that justify the interests of a group or class; second, a set of illusory beliefs, or "false consciousness", and third, "the general process of the production of meanings and ideas". The third and more neutral version, necessary of course for validating "socialist ideology", undercuts the first two (WILLIAMS, 1977, p. 55-71). The addition of hegemony to neo-Marxist vocabulary provided a kind of false synthesis by associating ideology with the production of ideas while suggesting that class interest and false consciousness might become hypostasized as a civilizational commitment. The latter occurs when the citizen's compliance is experienced as participation under systems wherein counterideologies and interpellations are democratically vetted and then run off to ground - thus permitting, for example, a silent majority to imagine itself to be a prepotent plutocracy.

After I had composed a draft of these thoughts I learned of Luis Villoro's book on the concept of ideology (VILLORO, 1985). I awaited it with certain trepidation, for I knew that this accomplished Mexican philosopher, with his analytic skills and sensitivity to historical process, might make my own reflections superfluous. If, having now read his adroit and lucid book, I find this to be only partly so, it is also clear that his argument is a necessary antecedent and accompaniment to mine. Villoro patiently defines the slippery terms statement, attitude, belief, and ideology. Applying both gnosiological and sociological analysis, he retraces the treatment of ideology by Marx \& Co. and mourns the paradoxical ideologization of Marxism itself. Thinkers who unmasked ideology so as to foster rationality and liberation only codified, he finds, a new instrument of domination. "Between science and ideology", Villoro asks, "is space left for philosophy?".

I am in admiring accord with Villoro's mission to demystify received clusters of philosophic thought and their subservience to vested interest. I applaud his distinction between the searching propositions of 
philosophy that liberates and philosophic codification that obscures and dominates. 1 agree, as Marx in enlightened moments insisted, that disruptive or liberating thought is impotent if unlinked to social transformation. What I resist accepting is the lugubrious procession that Villoro stages from philosophic speculation to codified doctrine to political manipulation to ideological control. "Unauthentic culture", he concludes, "is ideological culture".

As I see it, the accent of my argument differs on two counts. First, I want to rescue ideology, science, and philosophy from each other without severing them. The term "ideology", proposed by Destutt de Tracy in 1801, is less venerable than philosophy and science. Its ultimate meaning, however, underlies theirs since it has to do with cultural premises for belief and praxis. Ideology is a neologism that implies the commodification of moral sentiments in our industrial age just as entertainment implies commodification of the arts, even though art, as such, still endures. (Were there no precedent for my neutral use of ideology, I might have echoed Adam Smith and called this chapter "Notes toward a Theory of Moral Sentiments".) Villoro assumes that codified philosophy is doctrinal, an arsenal of muskets and not a cupboard of passkeys. He smoothly demonstrates (or alleges) that "democracy", "Mexican Revolution", and "socialism" are in the service, respectively, of capitalism, dependent underdevelopment, and Soviet bureaucracy, that they became ideologies of domination and not, as initially promised, levers for libertation. For me, philosophy and ideology may overlap or interfuse but are not sequential phases. In my usage they have different origins, legitimations, and constituencies. and avoiding distractive analogies with

philosophy and science, he set out a series of illuminating clues on how to reconceive ideology for a pluralistic world. historical emanation where, given its diverse sources, the challenge is not validation but interpretation. At the outset Villoro criticizes Mannheim's capacious and "vague" treatment of ideology as panideologism that collapses into the sociology of knowledge, whereas I take Mannheim as a transitional prophet between Marx's era and our own for whom analytic energies were yielding to historical empathy that was, at the time he wrote, necessarily more vague than Marxism.

Mannheim reexamined the question of ideology between the World Wars. Rejecting a Eurocentric viewpoint and avoiding distractive analogies with philosophy and science, he set out a series of illuminating clues on how to reconceive ideology for a pluralistic world (MANNHEIM, 1929). The anthropologist Geertz cautions against a supposed Mannheim's Paradox - to wit, that in striving toward a "nonevaluative concept of ideology" Mannheim resorted to normative postulates and thence to "an ethical and epistemological relativism" he found uncomfortable (GEERTZ, 1973, p. 193.233) ${ }^{6}$. Geertz himself, from his ahistorical, functionalist position, sees ideology and science as serving culture in two neatly complementary roles, ideology as its apologetic dimension and science as its diagnostic one. He consigns ideology to a justificatory, rhetorical function and science to an executive one that connects to "reality". My own view, more consonant with Mannheim's, is that ideology has its own executive force when it comes to human "reality". Science can in fact be considered to depend on ideology for its imagery and its agenda (although once ideology canonizes science, it risks converting it to scientism).

Dumont, whom I think of as Mannheim's more self-assured sucessor, is categorical on this point. He refuses to demote ideology form the company of science, philosophy, and other "reputable" domains: "there is already too much of a dovecote here". He locates the dilemma

6 Paul Robinson blows the whistle on Geertz' stylistic narcissism in 'From Suttee to Baseball to Cockfighting", The New York Times Book Review (Sept. 25, 1983). 
in the primal segregation of politics and economics from religion and society. For him ideology is not a residual category that absorbs left-overs from scientific and rational thought. It is not a mask or opiate, nor is it, even in the classic sense of the adjective, the rhetorical mobilization of Geertz. It delves to tacit premises, to the "grid of consciousness", to "implicit coordinates of common thought". Rationality and science clarify linkages between means and ends but cannot hierarchize the ends. Even in a scientific society science is not a referee but a team player in the ideological world series who breaks his collarbone like anyone else. Scarcely any modern citizen can demonstrate the heliocentric theory and none is even aware of it when watching a sunset. Neoscholastic Spaniards were quite candid; they fended off the Toledo blade of science simply by calling heliocentrism a fiction useful for maritime navigation. In our own day we expect the most progressive teachers and students to boo a Nobel laureate off the stage if he dares adduce "hard" somatic evidence for racial inequality. In the industrial West society and religion (belief) wait patiently on the sidelines, hoping for interstitial entry into what Chaui calls the "lacunar" or self-censored discourse of formal ideology (CHAUT, 1982, p. 3-13). During the Viet Nam War they waited well nigh interminably for the policy resolution of scientism (domino theory), individualism (massacre of innocents), and economism (tax burden and inflation). As we now see, Viet Nam imparteđ no moral lesson to the perpetrators.

Mannheim readdressed where Marx had left it the discontinuity between ideology as self-interest or false consciousness and as a process of rendering meanings. The former version had appeared with individualization and rationalization. The eighteenth-century businessman or intellectual required grounds for rational decision and freedom to think through issues affecting his private interests.

This was not the case for peasants or subordinate white-collar workers who had little bent for initiative or speculative foresight. As the religious world view disintegrated, although without vanishing, the absolute state asserted its political conception of the world as a weapon, based now on science rather than on articles of faith. With democratization, the task of fashioning a credo was relegated to liberals, then to conservatives, finally to socialists. All brands of politics took a scientific tinge while scientific attitudes assumed political coloration. Unlike academic discussion, political debate is not resolved on theoretical grounds. It strains to lay bare the motives of opponents, irrespective of the theoretical plausibility of their positions. Politicians aim to talk past each other, thinkers to engage.

Mannheim's Paradox is not then, as Geertz would have it, the stand-off between science and subjectivism - for the two are interfused - but a tension between the particular and the general which, as we will later see, were the terms that Rousseau had used at his own critical moment. Every moment in modern times is of course critical. The minds that interest us are those that experience theirs as so being. Mannheim first published Ideology and Utopia in 1929, a critical year to be sure; yet he found his "era of transition" laden with "antiquated traditions and forms". He had to revert to Hegel's acceptance of the Kantian dissolution of the world existing independently of mind and to the assumption that the world's unity requires a knowing subject. Mannheim, that is, shouldered the burden of German historicism.

Mannheim's pathology of nineteenthcentury Europe subtended a world arena. He was troubled by the transition from historical consciousness as such to Volksgeist (still "too inconclusive") to the doctrine of class idelogy. If this search was for the center of an infinitely variable world, it must fight shy of mechanistic synthesis. The fictional unity of "consciousness as such" must accommodate the outlooks of epochs, nations, and classes. Here Mannheim moved toward a global calculus once he had defined "particular" ideologies as a disguise for real situations and "total" ideologies as historic thought-systems grounded in noological coordinates. The latter contained yard-sticks to expose the 
deceits of the former. Mannheim saw around him a world in upheaval where beliefs and attitudes and even their intellectual foundations were under question. He commended Marxist theory for having fused particular and total ideology, using class and economic analysis to probe past a "psychological" to the philosophic level. Yet even this stage had passed, for socialists had lost their exclusive franchise for decoding bourgeois thought. Others could turn the new weaponry against Marxism itself. Weber, Sombart, and Troeltsch had pioneered the more agile strategy, and Mannheim quotes Weber's dictum that the materialist view of history is not a $\mathrm{cab}$ that one enters or alights from at will.

Reconciling particular and total ideology led Mannheim to posit a new phase, namely, the transition form the theory of ideology to the sociology of knowledge. Here the observer relaxes his grasp on absolutes in an era of "intellectual twilight" and recognizes that the meanings of our world are historically determined and continuously developing. In discarding fixed ideological values, a term redolent of the capitalist commodities market, we enter a realm of uncertainty that is closer to reality than were the absolutes of earlier faiths. As in the exact sciences, the uncertainty principle offers firmer anchorage than does certainty. The absolute, once a means of communing with the divine, now camouflages meanings of the present. We can read history only through patterns rising from flux Hence the anachronism of fixed values. The content of thought matters less than its categorical structure. A modern theory of knowledge entails not surrender to anarchic subjectivism, or relativism, but a search for historical understanding that is relational among spheres of thought, given that absolutes do not exist beyond incommensurable human contexts 7 . The danger of false consciousness is no longer that it fails to grasp a given state of affairs but that it lacks dialectical attunement to the ceaseless reordering of mental processes which compose our worlds.

While Mannheim derived his viewpoint from history, he was aware that in his "world of upheaval" it applied to contemporary cultures not less than to past epochs of his own tradition. From this threshold between Eurocentrism and pluricentrism he offered many clues, often allusive to be sure, for the challenge of ideological renewal in contemporary Latin America.

Two classic studies of race relations in the United States and Brazil help to exemplify ideological issues thus far raised (HEATH, 1974, p. 490-1/DA MATTA, 1979, p. 176) ${ }^{8}$. When Gunnar Myrdal and his associates presented their studies on the dilemma of blacks in the United States, they introduced the central volume with a statement of the American Creed against which treatment of blacks might be ineasured (MYRDAL, 1944, chap.1). This Creed, they found, had sources in, first, the ideology of the Protestant sects which envisaged democracy in prepolitical, ecclesiastical terms; second, the tradition of English law that laid bases for liberty, equality, and a government of laws rather than of men; and third, the humanistic liberalism of the Enlightenment and its principles of the dignity and perfectibility of man, a shared common weal, respect for consent of the governed, and a notion of liberty that was aggressively if loosely defined and assumed to derive form equality. This was perhaps the most explicit set of social ideals of any Western nation and the one most widely understood and appreciated by its citizenry. So compelling were its tenets that even blacks were "under the spell of the great national suggestion. With one part of themselves they actually believe, as do the whites, that the Creed is ruling America". One could scarcely find a clearer instance of ideological hegemony, or conditioned acquiescence in the precepts of a legitimized political order. Myrdal's challenge was to explain racial

7 On this point see Villoro's chapter on "Authenticity in Culture" in E1 concepto de ideología (1985).

8 I have drawn the contrast in "The Claims of Tradition in Urban Latin America" in Dwight B. Heath, ed., Contemporary Cultures and Societies of Latin America (1974). Roberto da Matta notes it in Carnavais, malandros e heróis (1979). 
discrimination, both legal and behavioral, given the spell of the American Creed.

In the 1950s another European, Roger Bastide, directed a set of comparable studies on race relations in Brazil (BASTIDE e FERNANDES, 1955) ${ }^{9}$. In this case no attempt was made to summarize a "Brazilian Creed" as a yardstick for social behavior. This could have been for several reasons. Perhaps in Brazil discrimination against blacks was not at a quantum jump from that against other disinherited groups. Or perhaps the researchers were being "realistic" in discounting formal ideology. Or perhaps they simply assumed the norms of a generalized Western ethic (the study had UNESCO sponsorship). Or perhaps, and this is what my argument supposes, there is no Brazilian Creed in the unitary sense of Myrdal. In the United States the imputation that a person or group is un-American carries a clear set of meanings, while in Brazil the term un-Brazilian would be something of a puzzle. If the term were coined, one might imagine it signifying "patriotic" respect for an authoritarian public order or else "patriotic" disrespect for that order; it might be applied to those who undermine legal norms of equality or to those who fail to exhibit the Brazilian kanck, or jeito, or circumventing formal codes. In short, the norm for being Brazilian might be derived from an exogenous constitutional criterion or from an endogenous cultural one.

Brazilian society, Da Matta has said, is one of multiple ethics. Here the liberal, individualist Western ethic is an official creed of legal equality that has no popular recognition as a prevalent or enforceable ideal. Private codes at all social levels and informal cult groups, sodalities, and festivals offer alternative constructions of society, methods of coping, assurances of community, and therapeutic release. Here then, an oppressive institutional order whitewashed by individualist, egalitarian ideology is complemented by a family of subcommunities aspiring to an egalitarianism that is personalist rather than individualist and therefore consistent with holism. The realm of popular religiosity, in particular, represents " $a$ subsidiary system that is gradualist, hierarchical, and compensatory: a system possessing an enormous and clear multiplicity of spheres, motivations, and ideologies"(DA MATTA, 1981, p. 245). Such a society classifies the single person relationally in the shifting context of his affiliations rather than atomistically by precepts of a common Creed. In the American case the Creed and the culture are seen as conjoined; Brazilians see them as unyoked.

How and when might ideology take form in a society which is, in a radical sense, more pluralist than a Western industrial democracy? Must it await a moment favorable for technocrats and charismatic leaders to devise a self-legitimizing regime? Does it require explosive and consensual redifinition of the rules of the game? Or is the society to fluctuate indefinitely, as Da Matta suggests, between quiescent periods when a logic of social complementarity allows a vision of the totality and episodes of crisis when this logic collapses and the cosmic leader is called in?

In addressing such questions, let us brashly assume that the time is ripe to start articulating ideology not for but in Latin America. It is not to be cut from whole cloth, nor cater to vested interests, nor preempt an arc on the left-to-right spectrum, nor address immediate policy matters. It will reflect inexpugnable historical contradictions whence it issues and the contemporary world that it faces. It will hierarchize aspirations in conformance to demonstrable circumstance and shared belief. We are not talking of totalitarianism, a ludicrous pretension to holism in egalitarian societies that corrupts science and manipulates history. (Cf. Thomas Mann's Mario the Magician). Nor do we mean populism (promises, promises, promises. . .). We commence, as ideological reconstruction must, with commonsensical renewal of lexicon. From the domain of society-and-religion

9 See also. Florestan Fernandes in: The Negro in Brazilian Society (1969). 
(or experience-belief or anthropology. philosophy or history-literature) we fumigate, item by item, the whole mystificatory terminology perpetrated by economics and political science: state, society, bureaucracy, class, interest group, hegemony, power, control, influence, management, decision-making, policy, plans, programs, resources, organization, allocation, distribution, development, theory, models, education, consensus, science, evidence, system, equilibrium, causality, rationality, and many more. Communities are not machines, and privileged actors are not omnipotent nor even very competent engineers. To conceive of societies as systems of power that is rationally exercisable without cultural or moral constraint produces a world of confrontation, terrorism, bulging penitentiaries, and defense budgets of a quarter of a trillion dollars. When expertise governs, violence is the last resort, or alas, sometimes the first. Machiavelli was right to warn of the hand of fortune in human affairs and Rousseau to insist on the therapeutic force of a (perhaps inconstant) general will. As was Foucault to invoke an "insurrection" of minor historical knowledges "against the institutions and against effects of the knowledge and power that invest scientific discourses" (FOUCAULT, 1980, p. 87).

\section{A Promising Conjuncture}

Before surveying some possible contours of fresh ideology, let me show why this is a juncture for doing so. There are three considerations. First, the domestic situation. Ever since 1760 , when a cautious meshing of ancient understandings to Enlightenment discourse began occurring in Latin America, large fissures have appeared in national platforms for ideological renewal. A horizontal fissure opens between the cosmopolitan discourse of cities that envisions a systemic construction of society and an accommodative, architectonic political culture that prevails at grass roots and in the psychology of every-day life. Vertical fissures open among groups of ideological innovators because for many reasons no system seems to fit an architectonic society. Hence the characteristically politicist form of Latin American political culture, where manifestoes, plans, pronunciamientos, and garantias rally support for charismatic leadership and, as an afterthought, append standard promises of social reform across the political spectrum. The Mexican Revolution is a familiar case. It was not that revolutionary messages were improvised and compromised, as happens in any upheaval, but that there were no

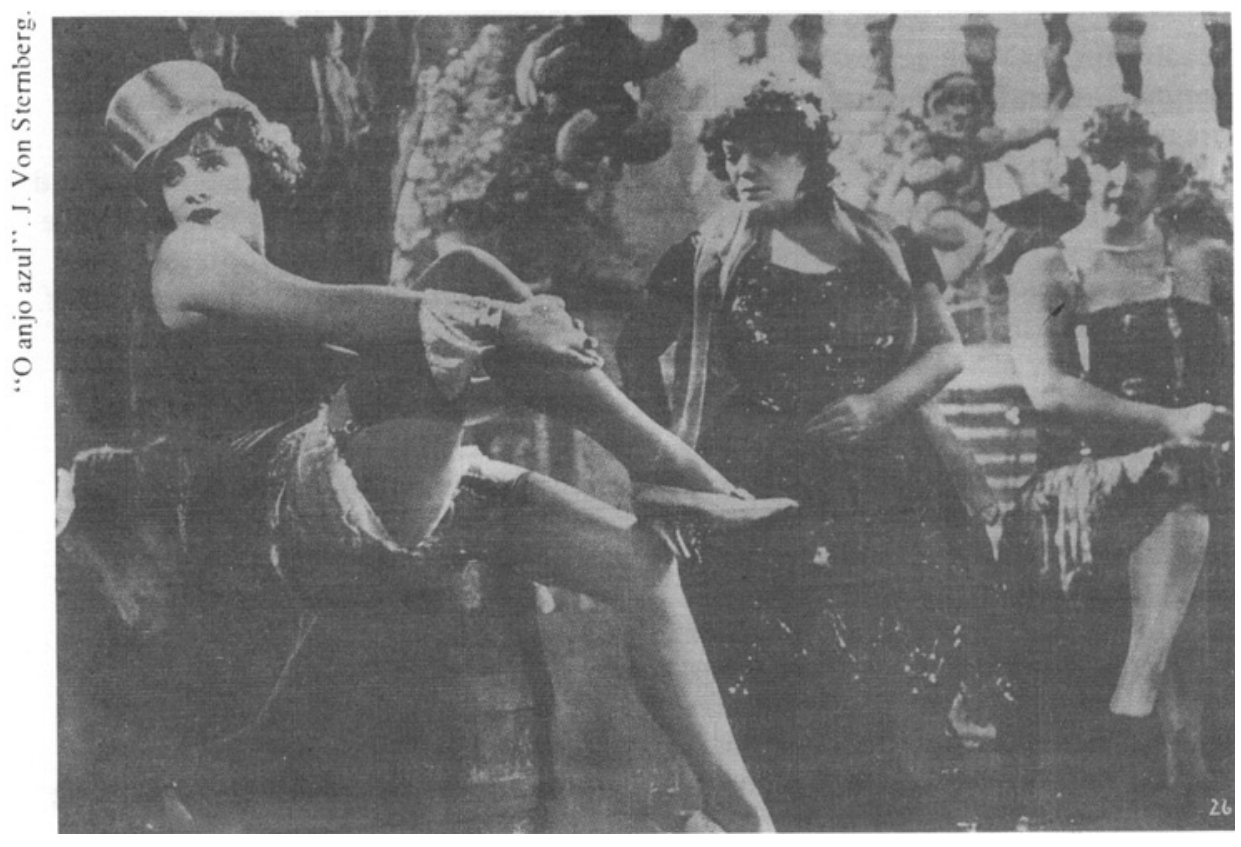


common understandings with respect to an elemental vocabulary and grammar for ideology (FROST, 1972, p. 143-95). These, as will later appear, are still lacking in Mexico.

Two centuries of random crises and arbitrary regimes never precluded meliorist hopes pinned to evolution, enlightenment, development, or simply a lucky cast of the revolutionary dice. Today, however, the future seems menacing and turbulent, at worst apocalyptic and at best inscrutable. Hence, the frenzied acceleration of paradigm shifts reviewed at the outset: kaleidoscopic nightmares of the academic mind that too often become waking dreams, as in Chile since the 1950s. Intellect becomes a loose cannon on the deck. It has gained mass and critical capacity. It is no longer a patronized establishment content to offer muted or encoded messages in lieu of sketching bold alternatives. Conversely, those who wield political power, often less competent than their predecessors, are losing authority to pacify intellect. The new universities, conceived for cooptation and technocratic recruitment, are a Frankenstein's monster. They command generous resources for reimagining the polity and for reconceiving history to yield a usable past.

Yet the new intellectual cadres cannot aspire to impose ideology as the pensadores once did. We no longer require armchair conjectures about natural men and social contracts. People are now part of society, despite sadistic protestations by social pathologists that they are, by computerized indices, at its margin. Glued to transistor radios, the people know what's at stake. They are in quotidian, dialectical confrontation with authority. They discover that their improvised sodalities for accommodation and solace harbor assertive, renovative force. If life is an opera, which the Brazilian writer Machado de Assis suggested it to be in chapter nine of Dom Casmurro, they are no longer supernumeraries but sing their own arias, now audible over the familiar score from the orchestra pit. (Note that Machado's God composed the libretto, Satan the music. "Indeed in some places the words go to the right and the music to the left. (...). There are obscure passages; the maestro makes too much use of the choral masses, which often drown out the words with their confused harmony. ")

The second conjunctural factor has to do with dilemmas of the industrial world. The metropolotian countries, alleged to control Latin American destinies, are internally threatened by economic uncertainty and exhaustion of cultural possibilities. Their life, hyperrationalized and disenchanted, spouts symptoms of paranoia and blind adventurism. Their ideological arsenal fails to yield an articulated polycentric scheme of the world. If such is the plight of hegemonic powers, Latin America is no longer an ideological consumer but has messages for the world. It requires its own ideological delivery system.

That the old sureties are crumbling and the future is murky makes the moment ripe for an ambitious ideological project. If one gets static on the TV tube, one extends the antenna for distant stations. The transmitters we might pick up are the great European ideologists who wrote at a time when ancient verities were in collapse, new bases for conceiving society were imperative, and to promulgate a viable future was an act of sheer intellectual fortitude. Yet we are not simply to select a new configuration of influences from great minds of the past. Rather, we must attempt imaginative reenactment of situations in which such minds - Vitoria, Hobbes, Rousseau (to whom we shall return), Hegel, et al. were thrown back on epistemological and axiological foundations to reconceive the polis. We quest not for propositions and formulae but for Aristotle's imitation of action. How does one revisualize society at an existential moment? The grand ideologists did so by looking to ancient and medieval exemplars and by cultivating an intuitive, anthropological sense of immediate circumstance. The ancients whom we look to are those very Europeans who attended the birth of the Western nations.

A third conjunctural factor deserves lengthier consideration. One does not invent ideology ex nihilo. Besides tuning in distant stations and having rapport
A Gramscian might propose that the artificiality and social fragmentation of the new nations precluded hegemonic ideologies. Florestan Fernandes contrasts the original bourgeoisie that created its own world with the "peripheral" one that accepts that world submissively and by diffusion. 
with immediate social circumstance, one must join a domestic conversation that has been framing the issues. An Englishman in 1650 or a German in 1800 did not reach out blindly to yoke Aristotle, Plato, Aquinas, and Machiavelli. He was immersed in contemporary dialogue. In Latin America such dialogue was desultory for a century after independence and often collapsed into soliloquies. Different explanations exist. Leopoldo Zea has claimed that New World "pensadores" were victims of futurism and failed to acknowledge and assimilate their own history. A Gramscian might propose that the artificiality and social fragmentation of the new nations precluded hegemonic ideologies.

Florestan Fernandes contrasts the original bourgeoisie that created its own world with the "peripheral" one that accepts that world submissively and by diffusion. Dumont might contend that Latin America, if one accepts it as one of the world's large family of holistic societies, could never digest the individualist ideologies of industrial Europe that had become its principal diet. Whatever one's mix of explanations, one may plausibly suppose that the period was a lost century for ideological reconstruction when one compares outcomes in such divergent cases as Russia and Japan.

Since the 1920s Latin American artists and intellectuals have been more successful in establishing cumulative dialogue. To evoke this ongoing process let us review several moments in the career of Latin American mind and sensibility in our century as reflected in such realms as literature, the essay, philosophy, and social science. This is no definitive mapping but a personal reconnaisance of openings toward what are frequently called national reality and cultural identity 10 .

Our first moment is the key to the rest, for it demonstrates engagement with the industrial West without mimicry. I refer to Spanish American Vanguardism, known in Brazil and Europe as Modernism. In Europe Modernism had early antecedents as an attitude both critical and celebratory of modernization. One might call it a cognitive assault on the contradicions of modernity. Not until its golden age of 1910-30, however, did Modernism, from its Parisian arena, make its impact on Latin America. At this point Europe experienced the crisis of nerve associated with technification, commodification, alienation, and rampant violence, as these found expression in neo-Marxian contradictions, Spenglerian decadence, and Freudian invasions of the subconscious. The Latin American prise de conscience required precisely this dissolution of evolutionary and meliorist rationales. Europe now offered pathologies and not simply models. Disenchantment at the center gave grounds for rehabilitation at the rim.

São Paulo was a predestined Modernist center. Once the impoverished homeland of Brazil's half-breed pathfinders (bandeirantes), it had exploded as the industrial capital of the continent. Herc young intellectuals were well positioned to adopt Modernist technique and, in their Brazilwood and Anthropophagy manifestoes, to use it for encoding messages directed to the metropolitan countries. Having filled the pockets of the capitalist West for centuries with exports of brazilwood, gold, and coffee, the time had come for Brazil to export poetry, to enrich and pluralize Western mind and sensibility. Anthropophagy recalled the cannibalism of Brazil's first natives, who neither rejected nor mimicked European culture but consumed its bearers to ingest their magic powers. José Carlos Mariategui, a Peruvian contemporary of the Brazilian Modernists and famous for his essays interpreting his nation's "reality", is not primarily remembered as a vanguardist. Yet he was in fact a devotee of surrealism which, by decomposing the solid bourgeois world into absurd fragments, showed him how to extract Marxism from its positivist armature to give its message mythic beyond merely scientific force (NUNEZ, 1978, p. 69-87).

Mariátegui's Seven Essays (1928), like Paulo Prado's Portrait of Brazil of the

10 The rest of this section draws on a chapter I am preparing for the Cambridge History or Latin America. 
same -year, linked Modernism to the national-character essayists of the 1930s. Here was a genre that paid heed to history, culture, philosophy, and psychology and less to economics and government, despite the world depression and its political crises. Ezequiel Martínez Estrada published his X-Ray of the Pampas in 1933, at the threshold of Argentina's infamous decade. Yet his $\mathrm{X}$-ray was not of sociogeographic reality in Mariategui's sense but of the Argentine mind. The quest leads to cultural and spiritual biography and, as it enters the domain of psychoanalysis, suspends historical time. The Argentine is an orphan of tradition, condemned to solitude, engrossed in a private self. Only when the specters of the past are brought to consciousness can they be exorcised to allow Argentines to live together in health. Germans from Schopenhauer and Nietzsche to Scheler and Spengler marked the cast of Martinez-Estrada's thought, as did Ortega and Freud. In this he was akin to Samuel Ramos, whose Profile of Man and Culture in Mexico appeared in 1934. Both men saw collective psychology as the key to national therapy.

From the invertebrate subcontinent of Brazil came a trio of books offering quite divergent diagnoses 11 . In The Masters and the Slaves (1933) Gilberto Freyre became a Freudian by private invention in his search for archetypes that govern behavior and institutions; his fascination with ethnicity, sex, and authority; and his inertial view of historical process. Much as Freud labored to normalize the idea of sexuality, so Freyre sought to legitimize Iberian culture in the tropics. In stark contrast, The Colonial Background of Modern Brazil of Caio Prado Junior in 1942 (preceded by an essay of 1933 giving a materialist interpretation of Brazil's political evolution) dismissed any nostalgia for cultural roots in rendering Brazil's past as a function of production, distribution, and consumption. Adopting a propulsive rather than Freyre's entropic view of history, Caio Prado explained change as a resultant of the international division of labor and the role played therein by stronger countries. Pradó's pioneer work would bolster the economistic argument twenty years later but, for the moment, offered little help for the identity quest because he disregarded cultural destinies and world outlooks.

In the third book, Roots of Brazil (1936), Sérgio Buarque de Holanda proposed a dialectical version of Brazilian history rooted in dyadic constructs of Weberian inspiration. His master split emerged as that between the affective and diffuse ties among persons in Brazil and the juridical assumptions of Western liberalism with its amoral balancing of private egotisms (Cf. Da Matta's analysis referred to above). While affect, or cordiality, is therapy for rationalization and depersonalization, it loses force beyond a small human circle; it cannot cement extended forms of social organization, nor is it a reliable source of normative principles.

For all their differences, the writers considered thus far addressed national reality by assuming a relation of tension between the Iberian legacy and the West at large. From this traffic between localism and universalim, new identities were to be forged. In the exchange, however, Latin America suffers handicaps: first, the mother countries could not endow their colonies with modern institutions and ideologies; second, contemporary Latin America remains traumatized (except in Freyre's view) by the predatory violence of European conquest and settlement. Yet to achieve identity would seem to require assuming at the outset that one finds oneself to be at a viable center.

\section{In Cuban Counterpoint: Tobacco and} Sugar (1940), Fernando Ortiz dispenses, except by implication, with history conceived as political and cultural invasion of an exotic periphery. Instead, he features two agricultural crops that define the native landscape of every Cuban. He starts with Cuban reality rather than working his way toward it. In this he is close to the lesson of São Paulo's Brazilwood and Anthropophagy

11 Antônio Cândido compares these works in his preface to Sérgio Buarque de Hollanda, Raizes do Brasil (1 969). 
manifestoes. He deduces his story from the biotic requirements of two forms of vegetation. Tobacco and sugar are defined not as currency in capitalist exchange but as products of Cuban soil that in themselves dictate institutional arrangements and ways of life. Ortiz starts with the land and its fruits (as did the early Marx and Engels in The German Ideology), not with human contrivances, and adopts the ludic and poetic attitude of the Modernists. Only after he personifies his two crops does he smuggle in the instrumental concerns of history (markets, economic organization, production systems), now subordinated to preexisting Cuban identity that Ortiz, the ethnologist, accepts with humor, assurance, and an eye to common-sense therapy.

The next step beyond the experimentalism and expressive release of the Modernists and the reconnoitering of the essayists was toward precision, consistency, and hemispheric generalization. A promising locus by the 1940s was Mexico, whose
Revolution had sunk roots, matured, and, it seemed, translated the disparate hopes of the 1920s into a program of domestic cultural inspiration. Political and economic developments that have cast doubt on whether a revolution did in fact occur still lay ahead. Two further factors enhanced the Mexican position. First, the Revolution was premature for true Modernists to have become guides. Older hands retained intellectual mentorship (Alfonso Reyes, Antonio Caso, José Vasconcelos) and could adapt to new situations within the large philosophic perspectives of an earlier period. Second was the exodus of Spanish intellectuals to Mexico in the $1930 \mathrm{~s}^{12}$. They came with professional, international-level competence in the arts, letters, and sciences. Their anti-dictatorial politics placed them to re-legitimize the central lberian component of Spanish American culture that had been so problematical since independence. As Europeans, moreover, they could expand the question of New World identity to its hemispheric dimension.

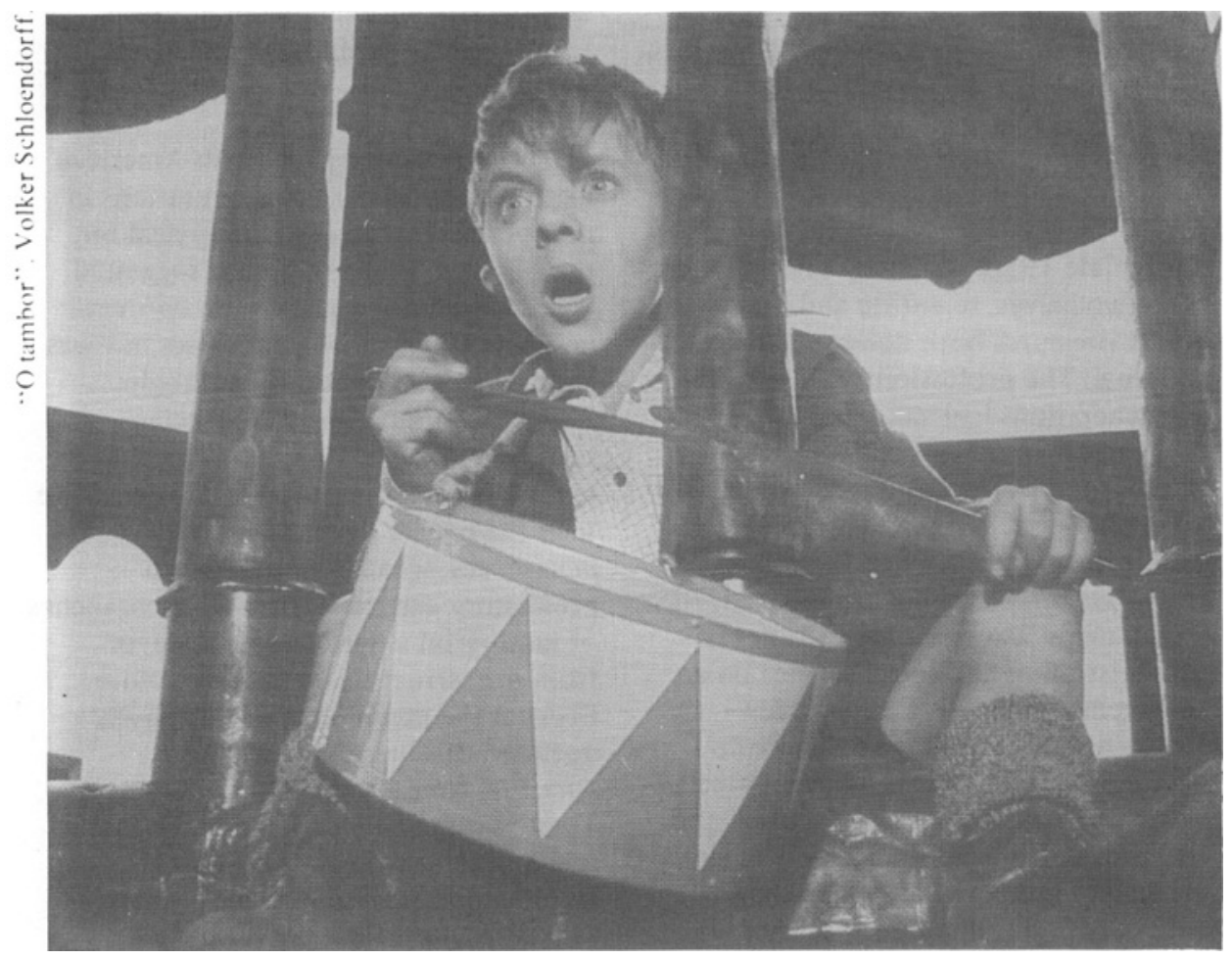

12 See El exilio español en México, 1939-1982 (1982). 
This moment of the twentieth-century prise was marked by the ascendaney of existentialism and phenomenology, diffused directly from France and Germany or via Ortega y Gasset and the Revista de Occidente. Although Spanish emigrés in Mexico gave anchorage and inspiration for what Miro Quesada calls the awakening of the Latin American philosophic "project", the movement was polycentric (MIRO QUESADA, 1974) ${ }^{13}$. In Argentina, for example, Francisco Romero was the complement to Jose Gaos in Mexico. Latin American philosophers, no longer mere

"pensadores", were now less hostage to circumstance and more confident in managing generality. Even Ortega's homily "I am my self and my circumstance" leads, epistemologically, from the general to the particular, not vice versa. Phenomenology echoed the pretensions of Catholic thought to universalism and self-legitimation. It could also claim the scientific rigor of positivism without relegating Latin America to an inferior stage of evolution. Finally, as Mannheim recognized, its historicism was congenial to the search for collective identity; it therefore provided a level of generalization appropriate for the vague but persistent notion of a Latin America civilization (MANNHEIM, 1929, p. 296-300).

In the late 1950s our story line splits into two halves, scientific and literary, under pressures both domestic and extemal. The professional schools that for generations had validated the status and careers of upper-class sons were ill-suited nurseries for the cadres needed to expand bureaucracies and private enterprise at a time when economic development was being internalized. The remedy was to create faculties of administration and social science on an emergency schedule. Earlier, a few institutions (University of São Paulo, El Colegio de Mexico) had attempted to adapt curricula to domestic society and culture. But the perceived need to apply science to human affairs was now so urgent and the funding for academic infrastructure so abundant that there was little time for judicious redesigning of foreign curricular models, much less for creative innovation in situ.

The apparent paradox was that the North Americanization of universities (with generous European and domestic accents, to be sure) occurred precisely when large sectors of the new academic establishment were drawn to one or another brand of activist or intellectual Marxism - or else simply to the idea of Marxism. After its transplantation in the revisionist version of Juan B. Justo and the "indigenous" version of Mariategui, Marxism had fallen into eclipse as a result of disenchantment with Stalinism in the 1930s, the Allied war against fascism in the 40s, and the developmentalist hopes of the 50s. Apart from the party apparatus, only a few intellectual stalwarts like Caio Prado Junior and Anibal Ponce, along with the Cuban journal Dialectica, kept alive its intellectual promise. Suddenly, with the economic polarization of national societies, the collapse of developmentalism, the loss of faith in the "benevolence" of international capitalism, and the stirring example of a "fresh start" in Cuba, Marxism regained its initiative.

The joint hegemony of North American methods and Marxist interpretations in the social sciences was paradoxical but not illogical. For, as we have suggested, Marxism did not represent an epistemic break with Ricardian economics but was its logical culmination. Both Anglo American empiricism and Marxian scientism strive to unmask a social reality that is more concrete and definitive than the realidad evoked by the pensadores, which had a Hegelian promissory cast to it. Both array branches of inquiry on a hard-to-soft scale, or from infrastructure to superstructure. Because the pensadores had implicity upended this hierarchy, the new scientists found them soft and subjective. There is no mystery, then, to the fluent academic traffic between empiricists and Marxists, for while their politics are poles apart, their ideologies, in Dumont's comprehensive meaning, are

13 See also his Proyecto y realización del filosofar latinoamericano (1981). 
similar. However much their therapies differ, both accept the vision of a Latin America that is host to implacable capitalist structures reaching to tive tapreots of society. and both fix upun highly instrumental goals.

For an ideological alternative to scientism we look to a fifth moment of the ongoing prise that is concurrent with the fourth. I refer to literary and artistic creation, although to retain focus I limit myself to the marvelous realism of the novelists. We must accept the fact that since the 1960s Carpentier and Garcia Márquez have become more recognized in the West at large than have Pablo González Casanova and Fernando Henrique Cardoso. One therefore assumes their messages to be of comparable significance. The challenge is to imagine what transaction might occur between novelists and scientists.

In the last century the debt that Marx and Engels owed to Balzac and Dickens was self-confessed: without the novelists' sweeping social panoramas, the scientists' understanding of commodification and reification in bourgeois, consumerist Europe would have been greatly impoverished. But what has the Latin American scientist made of One Hundred Yeur of Solitude, beyond cherishing it as a monument to domestic imagination?" The fact is that even a Marxist finds more useful evidence in treatises of the Chicago Boys than in the literary creations of his compatriots. Let me venture an explanation. The ideological split that has characterized Latin American

For an ideological alternative to scientism we look to a fifth moment of the ongoing prise that is concurrent with the fourth. I refer to literary and artistic creation, although to retain focus I limit myself to the marvelous realism of the novelists. intellectual endeavor since $c a .1760$ has sensibilitics of the past were quite awarc of it as were, for example, Machado de Assis and Mariategui in their different fashions. But now, at the present impasse, bifocality has become pathological and requires optometrical correction.

Simply stated, the issue is this. The scientists, whatever the provisos and finally become public. The keenest nuances of their analyses, rationally perceive Latin America as inserted into explicable schemes of metropolitan domination. manipulation, and desacralization ${ }^{14}$. The marvelous realists on the other hand, however leftist their political sympathies. instinctively "man'el at" the intransigent resistance of their socie ties to the imperatives of Western rationalism, capitalism, and political management. How do we bridge these two apparently antithetical visions? The very fact that the dialectic has become simultaneous rather than, as in our version of it since the 1920s, linear suggests finally the possibility, the multiple possibilities, for historical engagement - if not, in any simple sense, for sinthesis.

This is not he place for an exegesis of marvelous rcalism, for book-length treatments of the term are already in place 15 . Suffice it to distinguish between magic realism - which blends magic in to the world and creates ambivalence for causal interpretation and marvelous realism - which blends the unaccustomed (lo insolito) in to the workaday world, making the marvelous conterminous with reality without cliciting dread or porten tous mystery and without necessarily laying causal process under direct question.

How then do we connect the marvelous/magic realism of the literati with the neopositivism of empiricists, Marxists, and dependency theorists? And how do we explain that the novelists are more compelling than even the most agile and innovative of the scientists? Foucault gives us clues if we are at home in the rarefied air of French post-structuralism. But if we wish to pluck the fruit of understanding from our own garden, we consult those who are placed to make transactions at mid-point on the priapic scale of hard-to-soft specialists, namely anthropologists and historians.

14 Save for those who accept Foucault's reminder that "anything can be deduced from the general phenomenon of the domination of the bourgeois class. What needs to be seen is something quite different". (FOUCAULT, 1980, p. 100).

15 Cf. Irlemar Chiampi, O realismo maravilhoso (1980); Alexis Márquez Rodríguez, Lo barroco y lo real-maravilloso en la obra de Alejo Carpentier (1982). 
Historians. alas, have temporarily disqualified themselves as they fight the taint of humanism, deluging us with more charts and tables than even economists need. But the anthropologist, more secure in his scientific standing, risks speculative ventures.

The Brazilian anthropologist, we saw, finds his society to be one of multiple ethics. His culture confronts the scientific premises of Western thought with a seduced truth of African inspiration which, because it is symbolic, is also reversible. Thus the Western axiom that exchange creates surplus, and from it linear accumulation, may yield to the presumption that exchange is reciprocal and therefore requires restitution.

Afro-derived culture is not grounded in universal truth but in a seductive truth that toys with appearances and suspends universals as it seeks emancipation from sense and logic. The solemn resurrexit sicut dixit of the colonial prayer has become for the people Reco-Reco Chico disse. Once it is ritualized truth is relativized, purged of univocal, doctrinal meaning. Brazil's terreiros, or ritual arenas, become radiating centers that expose reversibilities of the global society (SODRE, 1983). Similarly in Spanish America, Colombian peasants and Bolivian tin miners, instead of surrendering abjectly to the commodity fetishism and human degradation of capitalism, resist the laws of economics by anthropomorphizing their domination in the form of contracts with the devil. In so doing, they reenact the first historical moment of subjection or enslavement to ressurrect a demonic figure who will thwart rationalization and dehumanization (TAUSSIG, 1980).

If the boundary between rationalization and enchantment were to coincide with a horizontal split between privileged and desinherited classes, we might assume that rationalization will continue a downward invasion through the social levels to produce a society that is available for massage or cooptation by a hegemonic ideology. But such is not the case. The Brazilian studies show that Umbanda cult organization, far from respecting class divisions, cuts athwart them and extends informal structures to the highest political and military levels (BROWN, 1979, p. 270-304). We have also the evidence of the novelists of the 1970s who pursued lo insólito not in the domain of the populace but in the careers of the caudillos who governed them and who confronted, in marvelous ways, the intrusions of Western imperialism (ECHEVARRYA, 1980, p. 205-28/MARTIN, 1982, p. 207-27).

The intellectual moments just sketched, while far from exhaustive, suffice to indicate, first, why and how the hard-soft construction of experience might bend toward one that lends philosophy, arts, letters, and religion a contextual role for scientific and policy-specific endeavor; and second, that the unfolding of sensibility has not been a linear but a multicyclical process to be apprehended simultaneously. The interactions, whether actual or imaginable, are endless. Because the last two of our moments, science and marvelous realism, both became public moments in the 1960s, strategic roles were created for minds of ambidextrous vocation such as pholosophers, anthropologists, a poet-pensador (Octavio Paz), a poeteconomist (Gabriel Zaid), or a literary critic-sociologist (Antônio Cândido). For being more closely engaged, the dialectic now carries us forward more swiftly while allowing, indeed requiring, recovery of Modernism, the identity essay, and Orteguian perspectivism. The respective authors are recovered, however, not as precursors but as participants. Their messages enter a forum for cumulative discourse.

\section{Rediscovering the People}

We seem to have floated to an ionosphere of words, images, and conjecture. But as recent centuries have increasingly distanced thought from its object (Cf. Cassirer's An Essay on Man), the acrobatics it performs to achieve rapprochement need not alarm us. In Latin America, where the organizational mind has not managed to impose itself on the general will, we must welcome a few verbal and conceptual calisthenics if we are to recover a reality that 
empiricism and Marxism do as much to disguise as to disclose.

What I have merely hinted at thus far is that Latin America's intellectual efforts since the 1920s (plot them as you will) aim toward discovering the people. Earlier Europeans knew this to be the starting point; but since people were not yet visible (history written from the bottom has come three centuries too late) they had to conjure up a presocial condition and then restage a presumed social contract-unless, like More and Montaigne, they started with the Tupi Indians. In this case they found that men are by nature natural, which Oswald de Andrade maliciously rediscovered with Anthropophagy. Locke was lucky enough to stumble on a definiton of people that seemed to recognize natural propensities yet afforded Western history a new point of traction. For Latin America such a definition is more challenging, first because the people are culturally diverse and socially segmented; second because the founding principles of Ibero-Catholic governance were shrewdly oriented to accommodate heterogeneity; and third because the motif of politics has for five centuries been social control rather than participation. Hence the obstacles to a hegemonic ideology that requires uncoerced assent to self-evident principles rather than evasive acquiescence in structures of authority.

Let us probe further into our ideological puzzle. One might make the case that the lot of the Latin American common man has scarcely improved since colonial times, perhaps even worsened. Without devising economic or psychic indices to prove the presumption, let us review the public agenda of the region which after two centuries remains largely unfulfilled: abolition of "servitude"; minimum welfare standards; republican institutions; universal political participation; internalization of technological innovation; domestic capital accumulation; safeguards against foreign manipulation and intervention. Latin America might seem to be in permanent stasis were it not that the new historiography discovers, for every century since the sixteenth, unceasing transition from caste to class, from personal to commercialized human relations. This neo evolutionary view suggests that fresh ideology should be forged in reaction to-and therefore on terms dictated by-impinging capitalism. But if an already "Western" agenda is so largely unachieved, why does the ideology from which it sprang seem eternally appropriate? Need we interpret Latin America "stasis" to represent sheer ineptitude for modernization, or does it betoken an intransigent historical identity with psychic resources more durable than even those of "hegemonic" nations? Is there a tacit ideology of resistance or, in a term that has regained currency, primal liberation that should be set against the Manchester agenda of peace, prosperity, and private indulgence? Is ideology inevitably "suppressive and lacunar," as in Chaui's description, or might it be premissive and pluralist? Can we, that is, start with a matrix or "grid of consciousness" as Dumont counsels, or must we accept only the modular units for a prefab house - the "agenda" outlined above - whose design was lost in shipment?

To imply, as 1 earlier have, that ideology in Latin America is in search of a social contract is a way of saying that it needs a temporal benchmark, whether historical or mythical. To constitute a polity is to enter history, and it is appropriation of history that bedevils the proto-ideologists whom we have considered. Brazilian Modernists prescribed symbolic reenactment of the Indians' anthropophagy, a ritual ingestion of foreigners and their powers. Essayists and neo-naturalist novelists found that noncumulative history is immersed in prehistoric geography. Ontologists asked whether Europeans truly discovered the New World or whether America is still being invented. Marvelous realists imagine a circular time that merges my th with present circumstance. All this makes one suppose that natural, precontractarian man still inhabits Latin America. Where can he be found?

Far be it from me to reinvent a creature who frequents the pages of Guimarães Rosa, García Márquez, and Roa Bastos. Instead with the help of the 
poet-economist Gabriel Zaid, let us make clear that he is not homo aequalis or economicus who arose with the Western revolution of values (ZAID, 1979). I choose Zaid simply because he can manage statistics while looking past them. He takes us to Mexico, but with queries that make the case emblematic.

Zaid's theme is "unproductive progress", and his master construct is a

"pyramided" society that offers one third of the population shelter under the pyramids. Like Octavio Paz, Zaid evokes Aztec imagery, in search not of historical continuities but of Foucaldian recurrent discourse. His emphasis seems apt for segmented Indo-American societies from Mexico to Bolivia. Comparable treatment of the Afro-American tier of societies from the Antilles to Brazil might give more play to an informal ethic of accommodation between common folk and the public powers. (The

Euro-American societies of the southern cone, which entered blockaded situations in the twentieth century, lack the ethno-ideological pluralism of Indo and Afro-America. It may be significant that the latter societies have been receptive to the praxis of Liberation Theology, while Argentine intellectuals were driven in the early 1970s to the more fuily conceptualized premises of Liberation Philosophy.)

Zaid takes Mexico as a society unto itself. After all, if a nation of seventy-five million souls has, during a century and a half, been painfully forged so that nearly all its people have at least a sense of belonging - if not of incorporation or participation - it would be cynical to insist that sovereignty is passe and that a "peripheral" nation is merely a puppet of external commercial and financial manipulations that even a Harvard or Sorbonne graduate student can scarcely unravel. A large national unit is still sovereign, and it can at any moment stop importing whiskey or Stanford educational advisors. More important, if it is a country with a limited home market, it can resolve not to satisfy insatiable needs $\grave{a}$ la Ricardo (production) but to provide would-be consumers with inexpensive means to satisfy their own modest and immediate wants. That is, ideology - whatever its universal attunements may be - is here to spring from an ancient community, cast in an idiom of self-recognition as well as norms and aspirations. It should not primarily react to systemic domination, for the society itself is not systemic but architechtonic (or pyramided). A people who make no consistent political contribution and provide a marginal and erratic market for products that the state incurs huge debts for producing is systemic in only a Pickwickian sense.

The canonical explanation that dominant classes control the pyramid of the state and the semi-autonomous pyramids of business, labor unions, universities, et al. collapses in to the tautology that groups of wealth and power tend to be dominateurs and not dominés. Hegel's analysis of the master-slave relation was more subtle, but Marx slyly stood Hegel on his head precisely to give his own argument an evolutionary, systemic outcome. Zaid attributes less to the feral instincts of dominateurs or the greed of international capitalism and more to blind acceptance of a systemic economics purveyed by progressive consultants. In the years 1970-76, when the caloric consumption of Mexicans decreased by $5 \%$, the budget of the National University rose by $600 \%$ and those of the provincial universities by $1,400^{\prime} \mathrm{i}$. One implication of this phenomenon is that the mere presence of the non-pyramided population feeds the growth of the pyramids. That is, a destitute village. simply by existing, creates a need for anthropologists, bankers, contractors. et al. The notion of distributing tax revenues directly to the people is ridiculed in light of the mural idiocy of folk who assume debts at $100 \%$ interest to buy plows and fertilizer which they know they must slave to repay. The pyramidal norm is an $8 \%$ loan, arranged through connections, for a trip to Miami or an extra car or a house which is endlessly pyramided through further connections. In this fashion the iron rationality of the dismal science is transmogrified into the euphoric credo of triumphalism. The pharaonic persuasion of course requires elaborate casuistry in the form of such axioms as: 
1) that constructing an immense urban cloverleaf to save bureaucrats ten minutes commuting to non-productive jobs is a better investment that fifty thousand bicycles for rural villagers; or

2) that chronic shortages of domestic food staples are less significant than the permanent availability of $J \& B$ whiskey, LP's (Vivaldi and rock), color TV. VW's, and vernacular translations of Lenin and Milton Friedman; or

3) that direct family remittances from migrants in Tucson and Los Angeles are less effectively spent than inter-governmental grants filtered through two national bureaucracies; or

4) that the target consumers for an industrializing country in Latin America should be the elites of Guatemala and Bolivia and not its own impoverished citizens. Merely to authenticate such propositions requires substantial overhead in fees to consultants from prestigious foreign untversities.

Had Zaid composed his book in the economist's usual fashion - a text cluttered with statistics occasionally relieved by an anecdotal footnote - his would have been another dismissable exercise in pathology. Instead he relegates statistics to a formidable appendix and raises anecedotes to the main text, where they assume biblical force. The "illustration" that compares the indigent potter's six sons, who work hard from childhood and marry only when they can afford it. with the economist's six sons, who marry and acquire children's tuition bills and mortgaged cars and houses long

The Iberian tradition is the native one. Its formal principle that political norms are anterior and external to the society has become archaic, and therefore its informal and still vital principle of populism (in the historian's sense, not the sociologist's) needs restatement in fresh context. before parasitic jobs in the pyramids are created for them, becomes a parable. Parables that illuminate moral dilemmas of time and place are or should be the essence of ideology, which we refuse to define as a grand blueprint, a mass opiate, a brave new truth of science, or verbal fetishism. The poverty of ideology in official Latin America is revealed when we contrast the economist, who preaches high-tech production of consumer durables (e.g., robots for São Paulo's Ford factories) that will substitute scarce capital for abundant labor, with the politician, who dreams of coopting the potentially articulate population into laddered. non-productive employment with the promise of cars, university education, and bypass surgery. Small wonder that the hard end of the knowledge spectrum has become hard like a gallstone, not like a cutting diamond.

\section{A Rogue Philosopher Lands a Hand}

Clearly the game of blindman's buff is ending. Deep change lies close ahead: not the arbitrary structural change promised by technocrats or revolutionaries in the 1960s nor a grand turnover in values but simple recognition of the long-term facts of the case. For guidance. we might stretch our antenna toward those distant transmitters. Three obvious sources of ideological inspiration are the Iberians from Vitoria to Suarez, the British from Hobbes to Smith and beyond. and the Germans from Fichte to Hegel to Marx. The Iberian tradition is the native one. Its formal principle that political norms are anterior and external to the society has become archaic, and therefore its informal and still vital principle of populism (in the historian's sense, not the sociolngist's) needs restatement in fresh context. The British principle (with its French Enlightenment corollary) represents precisely the Western revolution of ralues that, we finally recognize after two centuries, Latin American submits to in highly eclectic fashion. The central issue is no longer to internalize rationalization but to acknowledge permanent antibodies. The German principle is more congenial than the Anglo-French, for it arose in a recognized context of underdevelopment and directly challenged Enlightened tenets of Panglossian rationalism and oligarchic meliorism. As it matured, however, its apodictic universalism proved inhospitable to a plural ethic.

For various reasons we may be dissatisfied with these clusters of discourse. Despite their internal contradictions and points of dispute, they are general outlooks that accommodate to situations crées; they coast on premises that gradually escape surveillance. Our preferred guide would be an outcast, a rogue philosopher 
who challenges vocabulary and premises and not merely evidence, arguments, and prescriptions - a thinker who escapes the dead hand of a system by imposing private experience in its complexity. We surely have a choice of such rogues. Merely for demonstration let us try Rousseau. As a youthful picaro in Italy, Rousseau was exposed to the autumnal season of a patrimonial, Catholic society. In early maturity he collided with Paris and the smug pansophism of the philosophes. After he died, his alone of French Enlightenment texts caught the German imagination. Rousseau lived out a Latin American experience and, because all his writings are autobiographical, they presumably yield navigation markers. His points of reference were picaresque Italy, the philosophes' Paris that would soon deify Reason, and an (idealized) Genevan polis: all appropriate to our case 16 .

At the outset we dismiss the classroom questions of whether Rousseau was Jacobin or totalitarian (or both) or whether the Social Contract is internally self- consistent or whether the general will is compatible with representative government. We look for a grammar of ideology, not formulae. As Peter Gay has said, one should take Rousseau's political theory as a critical instrument, not a constructive device. Or: he is the theorist of democratic movements, not of the democratic state (CASSIRER, 1963, p. 27). However on interprets the Social Contract, one is left with the fact that when Rousseau addressed cases-Geneva, Poland, Corsica-he suspended $a$ priori judgments and weighed the historico-cultural facts of the situation. Throughout his life he held to the ideal of the polis as a self-styled citizen of Geneva; yet he never suppressed memory of his Catholic years in Italy as a periquillo sarniento 17 when he lived by his wits and learned that one must judge the self-given human being, that the fault of society is its guilt and not its organizational defects, and that a social contract is needed not to create a community but to give form to an existing one. One need not recover an archaic state of nature if society is everywhere present. To capture that society requires self-awareness, not sociology; if, then, it is rooted in persons, social thought should not, cannot, be systematic. Rousseau's professed metier in this period, and throughout his life, was that of musician, or one who deals in themes and orchestration, not propositions and systems. (Note the importance of Brazilian popular music for ideology in the 1960s and 70s.) (SANT'ANNA, 1978, p. 97-111, 223-42).

Let us group a few Rousseauian reflections to bring out three themes: the critique of liberalism, the principle of non-individualism, and the general will Rousseau's argument cut athwart the liberal presumption of society as an aggregation of self-made men divided intc colliding interest groups. This put the stress on private liberties rather than on liberty. It created false dichotomies between minority rights and majority rule liberty and order, liberty and equality, self-reliance and paternalism. Freedom begins with self and not with laws, Rousseau believed, and the self should submit not to laws devised by philosophers but to the idea of law as such. Where general interest is a calculus by experts, common good becomes a misnomer, for people no longer share a common life. Shared experience reduces to the capacity for private response to an alien environment. In Paris Rousseau was struck by the evanescence of the old Roman and Christian disposition for friendship, amicitia. In the Nouvelle Héloise

Saint-Preux observes that a man may be an instant "friend" on first meeting, yet years later may become an instant stranger if one asks of him a favor. A

16 In what follows, cognoscenti will recognize my debt to Ernst Cassirer, trans. and ed. Peter Gay, The Question of Jean-Jacques Rousseau, (1963) and Stephen Ellenburg, Rousseau's Political Philosophy (1976).

17 The "periquillo sarniento" was the picaresque protagonist of Mexico's first novel (1816), by J. J. Ferndndez de Lizardi. Katherine Anne Porter published her abridged translation as The Itching Parrot (Garden City, 1942). 
Parisian shows tender interest in so many persons that he can have no real interest in any of them.

Unlike the philosophes, Rousseau refused to consider the state as an improvable utilitarian machine for increasing happiness and enhancing welfare. This helps explain his attack on sciences and arts in the first Discourse (" (. . .) tell us what we must think of that crowd of obscure writers and idle men of letters who uselessly consume the substance of the State") and allows us to presume how he might have judged the academic Gradgrinds and policy pundits who thrive on our own public coffers. Personal liberty was for Rousseau not a mathematical but an ethical matter. One had, fatalistically, to accept inequalites, but not situations of control and dependency. Transformation of the social order required participation, not techniques of management, consent to law and not obedience to laws.

In denying that individualism was the foremost social principle Rousseau did not revert to Aristotelian and neoscholastic political man, a creature whose humanity pressupposed and was defined by sociability. Once society is constituted, however, men are, Rousseau believed, indebted to one another and to the state. Such indebtedness is not dependence but describes a relational community of artificial persons who are not by nature sociable 18 . Freedom does not therefore imply private spheres of non-interference, which lead to competitive disunity that causes one to depend on another's will. The rights of man cannot per se abolish coercion in society, for, in Ellenburg's examples, liberals are forever dispersing crowds, busting trusts, and splintering mass opinion. Moreover, to limit the quantity of power is futile if the source of power is tainted. If competition leads to slavery, so too does hedonism, since giving free rein to appetite is a form of personal self enslavement. The political whole must be non-aggregative and greater than the sum of its parts if it is to make possible the foresight and judgment that the presocial condition denies. From this assumption the question is not how to articulate parts into a systemic whole but how to respect the principle of diffuseness in the body politic.

From all this it follows that Rousseau distrusted the distinction between public and private, for when liberty is relegated to a private sphere, it is subject to public encroachment. His master split is between the general and the particular. All groupings (family, occupation, class, magistracy, and the like) are public but particular associations that fall within the general circumference of the state, defined as a society of citizens. Instead of the boundaries drawn (though often preferentially suspended) in both liberal and corporatist polities between conflictive private and public entities or sectors, we have here a hierarchical set of loyalties that runs from the particular to the general good, with the latter taking precedence. This social ideal lessens the importance of individualism, whether seen as a cult of Romantic genius and charismatic heroes or as a broad pedagogical program for cultivating latent abilities of single citizens. The alternative, however, is not dreary leveling and regimentation. It is simply recognition that genius or mere self-improvement is not a private matter but the corollary to unfolding, communally patterned social life. Genius depends for its definiton on a shared history.

\section{Contemporary society was, in}

18 The small Mexican town described by Diaz exemplifies this Rousseauian condition rather than the family and community solidarity often imputed to Latin A merican village life. "Any unit has existence only in reference to a given ego. For every ego in the community the set of people with whom he maintains patterned interaction is different. Consequently, there is no basis for friendship. Allegiances and alliances are crosscutting (...). The total society, like the family, is arranged into a series of separate, divided social roles hierarchically arranged." Yet this is not "capitalist" individualism, for the innovator or social climber is a laughable rather than a respected figure. In Catholic societies, as Weber observed, the virtuoso is under suspicion. May $N$. DIAZZ, Tonalá: Conservatism, Responsibility, and Authority in a Mexican Town. Berkeley, 1966. p. 134-35, 213. 
Rousseau's view, a legalized state of war declared by a powerful minority against the defenseless poor. For him, then, the central concern was not social engineering but the moral choice between liberty and slavery. Of Marx he might have said that he tried to eat his cake and have it too, and of Bentham that he ate a cake that wasn't his to eat. As for Erich Fromm, Rousseau was willing to dispense with the caviar of freedom to if one had the rice and beans of freedom from. Rousseau envisioned a radically egalitarian society with negative liberty for all, that is, with each being free of the will of another. Inequality of possessions is to be expected as long as it is not so exaggerated as to allow sale and purchase of persons. The more the gap widens between rich and poor, however, the more the rich abdicate responsibility and weave the chains of oppresion with garlands of art, literature, and science.

The much debated general will requires recognition of society as mutual and not devised or imposed association. For example, what Taussig's Colombian peasants demand is not fictitious equal pay for equal work that feeds capitalist expoliation but acknowledgment of the intrinsic worth of all persons. Chaui criticizes "release" of women from home-making to the competitive labor market because they continue to sustain an exploitative system (CHAUT, 1983, p. 112). Maria Hermínia de Almeida generalizes the point in implying that the primordial assignment for people in a non-participatory polity is to "bear witness", not to plead for an advantaged mechanism of incorporation (ALMEIDA, 1983). Ultimately general will requires bonded fellowship and reciprocal conditions of social life. In this, it "forces people to be free". For liberal pundits the phrase smacks of totalitarianism. Ellenburg advises us to reexamine the French, "forcer d'être libre", and to ask whether this means to force or to strengthen, in Rousseau's sense of virtue as a strengthening of the soul. If the latter, we are left with modern conscientization that resists internalized domination, or hegemonic ideology. Such resistance, one presumes, is more easily mobilized in a society of personalized status ascription (where confrontations provoke Da Matta's intimidating question "Do you know whom you're speaking to?") than in one where authority wields the scepter

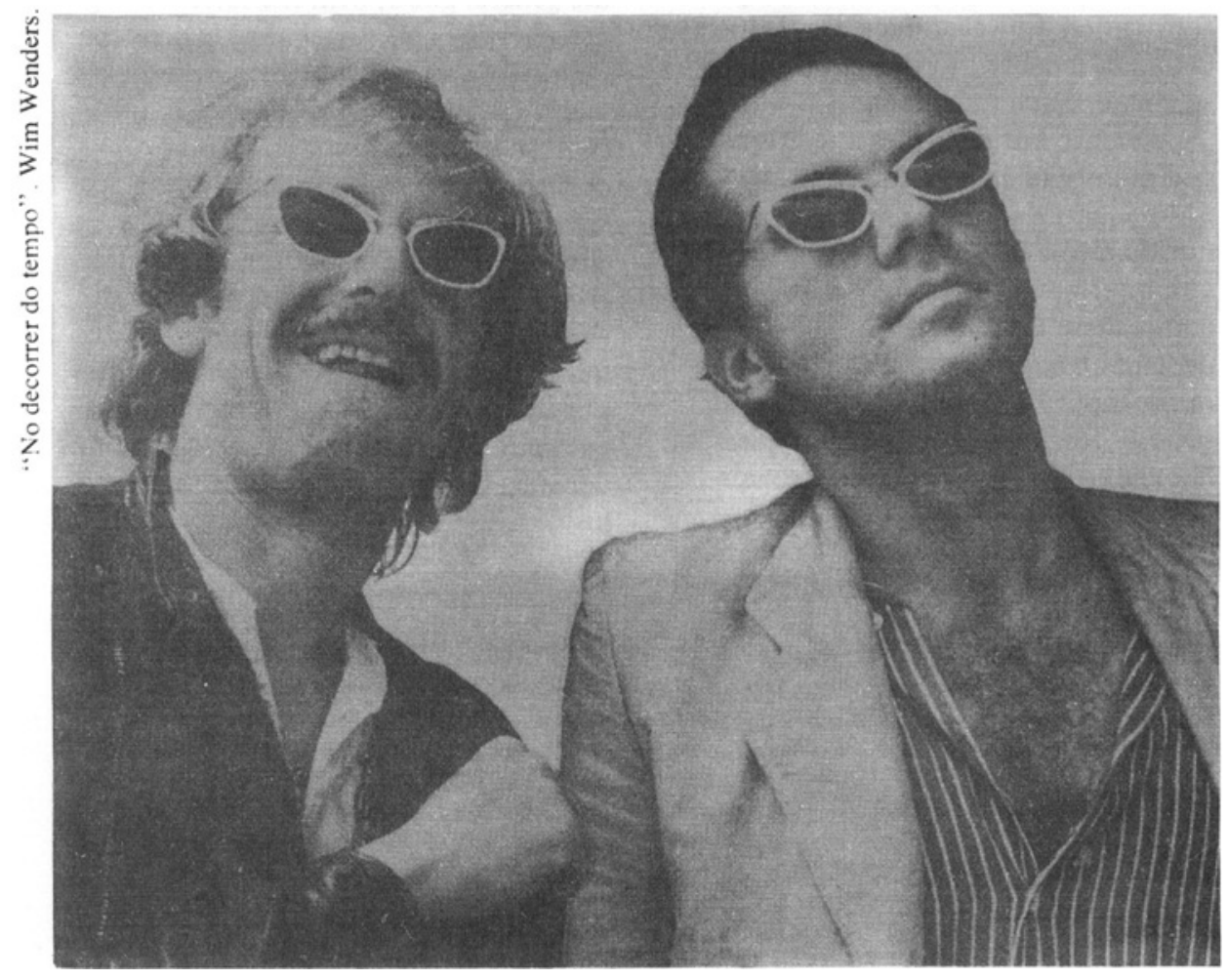


of egalitarian rationality (Chaui's principle of Organization) with its intimidating "who d'ya think you are?"

Let us now place Rousseau in the context created by our having reviewed Latin America's prise de conscience since the 1920s and having taken Zaid's Mexico as emblematic, though not descriptive, of contemporary Latin America. In so doing we look to Rousseau not for prescriptions but for perspectives. We even create our Rousseau as Suárez created an Aristotle or British liberals created their Magna Charta ex post facto. That is, modern Latin America might discover him to be a founding father in the sense of Borges that a writer creates his own precursors. Had Kafka not lived, we could not read Browning as we do. Did Latin America not exist, Rousseau's meanings would be more obscure.

If we assume that Zaid's image of Mexico has held for half a millennium and that it won't be unfamiliar to our great-grandchildren, we wonder whether a program of economic development, abolishing poverty à la Lyndon Jolunson, creating formal mechanisms for increased political participation (and cooptation), and schooling for selective release (and cooptation) of individual talent-whether such an agenda, rooted as it is in heavily skewed political and economic infrastructure, responds to the situation. It would seem that we should start from an integral vision of a somewhat passive society rather than with a set of urgent assurances of technocratic redemption and dialectic movement. Rousseau was not a utopian, nor did he claim to have discovered evolutionary process, natural or man-made. He might, however, have started with the premise that the total population of a Latin American society is already in the polity, that it needn't await a signal from Milton Friedman or the Marxists, nor the outcome of an academic debate over marginality, to determine who, by socio-politicoeconomic indices, is in and who is out. Mexico and Brazil and Paraguay and Guatemala already belong to their inhabitants. This assumption shifts the focus from a Ricardo-Marxian emphasis on mechanisms of change and instruments of power to an acceptance of fait accompli. This issue is not how to change but how to acknowledge what exists.

If we are to rescue the future from politicians, vested interests, scientists, and technocrats, we come up against Rousseau's threatening general will. Does this general will, we may ask, not open the gate to totalitarianism, guided populism, or, in the classic terms of Madison's tenth Federalist paper, a majoritarian "impulse of passion, or of interest, adverse to the rights of other citizens?" But these are manipulated phenomena. Rousseau's general will emanated from the people, not from self-appointed managers and curators. To be sure, the general will is inconstant, because it depends neither on verifiable principles of calculation nor on hoary precepts of natural law. Yet, if it is a direct emanation from the people, we have less to fear from it in pluralist societies such as the Latin American than in a factionalized Western society whose pluralism consists in multiple interests that rest on shared philosophic assumptions. Rousseau urges us toward non-systemic situations, where the task is to make the whole diffuse, not vice versa as in the mimetic centralist-federalist construction of Latin American politics. Why, if multiple realities are entertained, should political discourse not reflect them? Rousseau says nothing, as far as I know, that precludes diverse interpretations of the universe or that attributes universality to Weberian disenchantment or that denies the possibility of marvelous realism.

Admittedly, Rousseau preferred small societies to large ones. To the Cuba of 1959 or the Nicaragua of 1979 he might have wished to apply his Corsican recipe for small nations of social youthfulness adaptable for small farming and amenable to moral in lieu of commercial imperatives. Brazil or Mexico more nearly answer his Polish case : a large nation of soldiers and academies that cultivates arts and sciences, commerce and industry, where money is made to circulate swiftly so as to keep citizens in great dependence. This was the perfect formula for a scheming, 
avid, ambitious, servile, and knavish people given to extremes of opulence and misery, license and slavery. Rousseau's advice for such a nation was to revive the autonomy of provincial and smaller territorial units. Lacking the ideal small polity, one aims to segment the larger whole in defiance of systemic articulation. The representation one cultivates is not delegated power that may enslave those who delegate it but a direct and continuing representing of the political claims and world views of heterogeneous constituencies in search of liberation.

In contemporary Latin America the Christian base communities and Liberation Theology are an obvious analogue to the Rousseauian prescription. Here religion assumes the public, civic character that Rousseau advocated. By assembling in primary groups the people become the church, inverting and decentralizing authority, eliminating the paternal funcion of clerical "shepherds", acquiring the right to speak directly to the highest authorities. The constant dialogue that sustains and justifies the communities is a critical reflection on self and society, a search for causes of poverty and oppression that points toward collective understanding and ideology. Sin no longer means heterodox beliet but any form of oppression. To eliminate sin requires not a canvassing of received doctrines but alertness to signs of the times and a communal effort to devise fresh language, ideas, projects. Such a process seems closer to Rousseau's notion of a general will in gestation than to Anglo-American suppositions about opinion formation in a liberal society.

\section{A Footnote on Multiple Ethics}

This chapter has been concerned not with immediate issues and practical strategies but with the implications of a long-term existential interlude that is starting to witness, on many fronts, a deep-cutting reconceptualization of Latin American societies, institutions, and their cultural premises. As I reached these final paragraphs, a letter arrived from an accomplished Peruvian social scientist and planner who writes:

"At this moment something more than a preoccupation is apparent in the Latin
-American region. I would call it anguish sprung from the sensation that our distance from the industrial world and leading-edge technologies is increasing at biometric rhythms. On the other hand there is a sense of loss of identity, of dissolution of one's own, that doesn't mean transformation into an 'other' but into a vacuum marked by frustration where the only conceivable salvation is in the hands of economists and financiers."

Yet it is precisely such all existential moment - marked by anguish, vacuum, frustration - that invites and compels a surveying of native grounds and cultural roots. And it now comes at a time when the venerable Ibero Catholic tradition can be remembered not as exclusively clerical and authoritarian but, like any long-lived tradition, as carrying its own therapeutic potential.

This is not to say that the Christian base communities just mentioned are in themselves the answer (who knows what forms of cooptation they lend themselves to?), any more than the guerrillas, squatters' invasions, and non Catholic cult groups that opened our eyes in the 1960s were the answer. (And who, after all, can predict what burdens and ironies are subsequent to any "liberation"?) The point is that in the long run the

formation of radically egalitarian sects against a pyramided church (à la

Troeltsch and Weber) offers a better sociological example for Latin America than the disquisitions of Madison, Mill, Marx, and Gramsci.

This leads me to question Chaurs nimble essay "Popular Culture and Religion", which repudiates any and all religious sects because they are cooptable by institutionalized authority (CHAUI, 1982, p. 71-83). My own inclination is to keep religion right where Kierkegaard placed it along with ethics, art, and science. Chaui does, I admit, end up where I would like to, with the Frankfurt School admonition that science (not religion) is the opiate of the people. But despite this turn of the screw, her analysis is embedded in received Western philosophy; she urges use of its resources to replace the suppressive, lacunar discourse of "ideology" with an antidiscourse, or critical discourse, that will unmask
Latin America societies are societies of multiple ethics, whereas the ideology of the industrial West presumes a unitary ethic or as Americans like to put it, uniform niles of the game. 
ideology (CHAUT, 1980, p.22-3). The objective at this exploratory, formative moment, however, is not to calibrate Western ideology against Westem science but to canvas coexistent modes of discourse from wherever they may arise. Rousseau, unlike his Enlightened confrères, encouraged such an enterprise.

Here indeed is a central point. Latin American societies are societies of multiple ethics, whereas the ideology of the industrial West presumes a unitary ethic or, as Americans like to put it, uniform mules of the game. Such rules characterize egalitarian societies and are conducive to dissemination of hegemonic ideology. In Latin America heterodox world views, notably (but not exclusively) Amerindian and African ones in their creolized form, still persist. And they do so for two reasons. First, the action of church and state for three colonial centuries worked to orchestrate and hierarchize diverse world views, not to suppress or standardize them. Second, in societies where large masses could never realistically aspire to incorporation within bourgeois society, it is natural that heterodox outlooks and strategies for reconceptualizing the social universe have retained their force. How then can ideology in the sense of universal political ground rules flourish in societies that are truly plural and not merely factionalized?

Let us take a elue from Chemoff's contrast between Western and African music, whose implications are conspicuous for the Afro Caribbean countries and Brazil (CHERNOFF, 1979). For the moment, or perhaps for any moment in our existential future, we cannot expect clear, practical alternatives. What we do require is sensitivity to simultaneous constructions and rhythms. This we find in Chernoff's comparison between the Western "metronome sense", which construes time as moving inexorably toward a distant moment, and African music, which imposes on musician and spectator alike the need to maintain a personal rhythm that gives coherence to an ensemble of conflicting rhythms and accents. Western music harmonizes different tones into chords but has no name for rhythms; its terminology (accelerando, rubato, syncopation, and so on) refers to speed, meter, and accentuation. In Africa, beats have names and variations, and the beat of music comes from a relation among rhythms rather than from a dominant pattern. Alternatives remain alive. Translated into sociopolitical terms, this is the metaphor that illuminates our case. The fact that the establishment may coopt religious cult groups is of no more consequence than that New York and Paris night clubs convert African rhy thms to me cronomic linearity for the amusement of bored bourgeois patrons.

This aftherthought is by way of underscoring what democratization must mean in lands of cultural diversity where economic "solutions", by norms of the industrial West, are unattainable in a foreseeable future. Here ideology must evolve from the continuous representing of the people's claims, not from imposition via structures conceived on high. Democracy must here be thought of as a process that refers not simply to the everlasting clash of passions, interests, and opinions but also to the premises from which they spring and the arenas wherein they are voiced. The path of liberation that Latin Americans are adopting betokens a processual goal and not the static condition of Anglo-French liberty.

References

ALMEIDA, M. H, 1983. Novo sindicalismo e política. In: Conference on Opportunities and Constraints in Peripheral Industrial Society. Nova Friburgo, 1983.

BASTIDE, R. \& FERNANDES, F. 1955. Relaçōes raciais entre negros e brancos em São Paulo. São Paulo.

BERDY AEV, N. 1960. The origin of Russian communism. Trans. R. M. French. Ann Arbor.

BROWN, D, 1979. Umbanda and class relations in Brazil. In: MARGOLIS, M. L. \& CARTER, W. E., eds. Braztl, anthropological perspectives. New York. 
CASSIRER, E. 1963. The question of Jean-Jacques Rousseau. Bloomington.

CHAUI, M. 1982. Cultura e democracia. 3ạ ed. São Paulo.

1983. O que é ideologia. 12a ed. São Paulo.

CHERNOFF, J. M. 1979. A frican rhythm and A frican sensibility. Chicago.

DA MATTA, R. 1979. Carnavais, malandros e heróis. Rio de Janeiro.

1981. The ethic of umbanda and the spirit of messianism: reflections on the Brazilian model. In: BRUNEAU, T. C. \& FAUCHER, P., eds. Authoritarian capitalism. Boulder.

DUMONT, L. 1971. Religion, politics and society in the individualistic universe. Proceedings of the Royal Anthropological Institute, London, 1970.

1977. Mandeville to Marx, the genesis and triumph of economic ideology. Chicago.

1980. Homo hierarchicus. Trans. Mark Saintsbury et al. Chicago.

ECHEVARRIA, R. G. 1980. The dictatorship of rhetoric/The rhetoric of dictatorship. Latin American Research Review, 15(3): 205-28, 1980.

FERNANDES, F. 1977. A sociologia no Brasil. Petrópolis.

FOUCAULT, M. 1980. Power/knowledge. Ed. Colin Gordon, New York.

FROST, E. C. 1972. Las categorlas de la cultura mexicana. Mexico City.

GEERTZ, C. 1973. Ideology as a cultural system. In: The interpretation of cultures. New York.

HEATH, D. B., ed. 1974. The claims of tradition in urban Latin America. In:

. Contemporary cultures and societies of Latin America. 2nd ed. Ncw York.

MANNHEIM, K. 1929. Ideology and utopia. Trans. Louis Wirth and Edward Shils. New York.

MARTIN, G. M. 1982. On dictatorship and rhetoric in Latin American writing: a counter-proposal. Latin A merican Research Review, 17(3): 207-27, 1982.

MIDGLEY, E. B. F. 1983. The ideology of Max Weber, a Thomist critique. New Jersey, Totowa. MIRO QUESADA, F. 1974. Despertar y proyecto del filosofar latinoamericano. Mexico City.

MORSE, R. M. 1978. Manchester economics and paulista sociology. In: WIRTH, J. D. \& JONES, R. L. Manchester and São Paulo, problems of rapid urban growth. Stanford. (Portuguese trans. In: Dados 18: 33-56, 1978).

1988. O espelho de Próspero. Sâo Paulo, Companhia das Letras.

MYRDAL, G. 1944. An American dilemma. New York.

NÛNTEZ, E. 1978. José Carlos Mariátegui y la recepción del surrealismo en cl Perú. In: La experiencia europea de José Carlos Mariátegui y otros ensayos. Lima.

SANT'ANNA, A. R. 1978. Música popular e moderna poesia brasileira. Petrópolis.

SHERIDAN, A. 1980. Michel Foucault, the will to truth. London.

SODRE, M. 1983. A verdade seduzida, por um conceito de cultura no Brasil. Rio de Janciro.

STANFORD UNIVERSITY BULLETIN. 1983. Courses and degrees 1983-84. Stanford University Bulletin, series $31, \mathrm{n} \% 45$.

TAUSSIG, M. T. 1980. The devil and commodity fetishism in South America. Chapel Hill.

VILLORO, L. 1985. El concepto de ideologia y otros ensayos. Mexico City.

WIARDA, H. J. ed. 1982. Politics and social change in Latin A merica: the distinct tradition. 2nd ed. Amherst.

WILLIAMS, R. 1977. Marxism and literature. Oxford.

ZAID, G. 1979. El progreso improductivo. Mexico City.

Bibliography

CHIAMPI, I. O realismo maravilhoso. São Paulo, 1980.

ELLENBURG, S. Rousseau's political philosophy. Ithaca, 1976.

FERNANDES, F. The negro in Brazilian society. Ed. Phyllis N. Eveleth. New York, 1969. 
HOLANDA, S. B. Ratzes do Brasil. 5, ed. Rio de Janeiro, 1969.p. xviii.

ILLÁN, D. M. José Carlos Mariategui y su pensamiento revolucionario. Lima, 1974.

MIRO QUESADA, F. Proyecto y realización del filosofar latinoamericano. Mexico City, 1981.

RODRIGUEZ, A. M. Lo barroco y lo real maravilloso en la obra de Alejo Carpentier. Mexico City, 1982.

WESSELL JUNIOR, L. P. Prometheus bound, the mythic structure of Karl Marx's scientific thinking. Baton Rouge, 1984.

\section{Richard M. Morse}

Richard M. Morse, 66, nascido em Summıt, Nova Jerscy é historiador e professor desde a década de 40, tendo sido professor-visitante em Harvard, Columbia. Stanford (EUA) e professor da Universidade $\mathrm{cm}$ Yale. Autor de livros clássicos,

como From community to metropolis: a biography of Säo

Paulo (publicado em portugués em 1954 e reeditado pela editora DIFEL, sob o título Formação histórica de Sâo

Paulo, em 1970) e El espejo de Próspero: un estudio dialético del Nuevo Mundo (1982, México, Siglo XXI, recentemente traduzido para o português e publicado pela Companhia das Letras), é atualmente o secretário-geral do "Latín American Program" do Woodrow Wilson

International Center for Scholars, o centro de estudos avançados afiliado ao Smithsonian Institution (Washington,

DC). Richard Morse já participou, em duas ocasiôes, das atividades do Instituto de Estudos Avançados da USP, como professor-visitante: em julho de 1987 , onde integrou o

Simpósio Internacional Interpretaçōes Contemporáneas da América Latina e desenvolveu o presente texto, e em julho de

1988, onde coordenou o Simpósio Internacional

Democratizing Economics: discourse and praxis (Towards a New Economics).

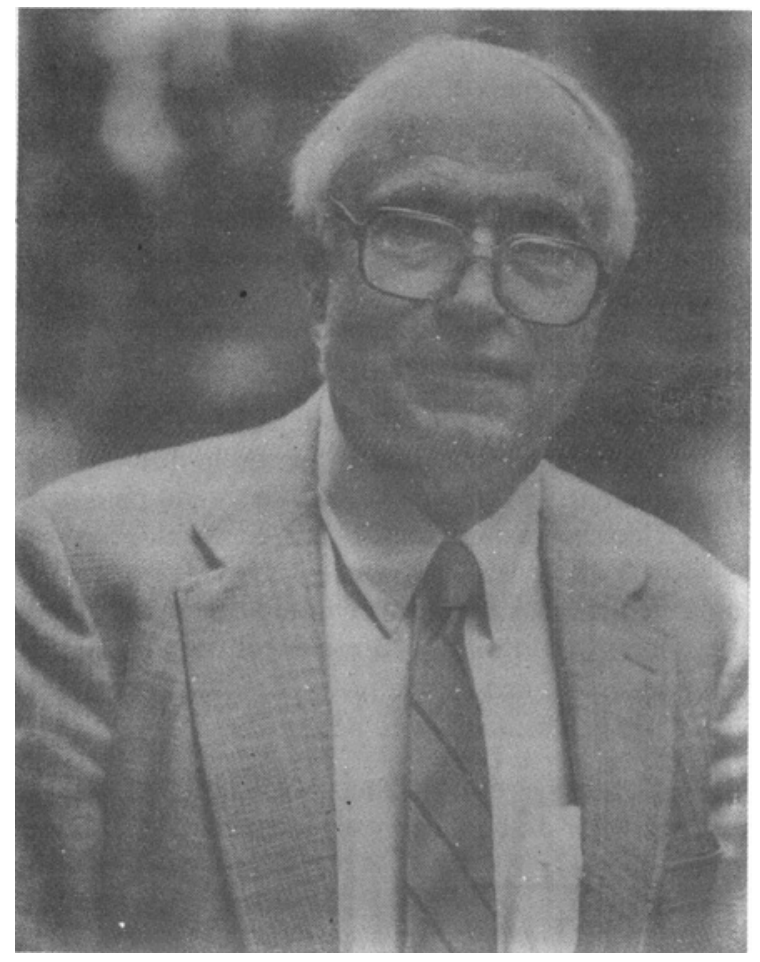

